Estudios Constitucionales, Año 14, № 2, 2016, pp. 15-52

ISSN 07180195

Centro de Estudios Constitucionales de Chile Universidad de Talca

"Los principios ético-morales de la sociedad plural y el Bloque de Constitucionalidad.

Configuración y desarrollo en la Jurisprudencia Constitucional boliviana"

Alan E. Vargas Lima

\title{
LOS PRINCIPIOS ÉTICO-MORALES DE LA SOCIEDAD PLURAL Y EL BLOQUE DE CONSTITUCIONALIDAD. CONFIGURACIÓN Y DESARROLLO EN LA JURISPRUDENCIA CONSTITUCIONAL BOLIVIANA*
}

\author{
THE PRINCIPLES ETHICAL-MORALS OF THE PLURAL \\ SOCIETy ANd CONSTITUTIONALiTy Block. Configuration AND \\ DEVELOPMENT IN BOLIVIAN CONSTITUTIONAL JURISPRUDENCE
}

\author{
Alan E. VARGAS Lima** \\ Miembro de la Academia Boliviana de Estudios Constitucionales \\ alanvargas84@hotmail.com
}

RESUMEN: En ocasión del séptimo aniversario de la Constitución Politica del Estado Plurinacional de Bolivia, considero pertinente comenzar precisando qué debemos entender por la palabra Constitución, su trascendencia y alcances como Constitución Normativa, para luego rescatar el relevante desarrollo jurisprudencial que han tenido los principios ético-morales de nuestra sociedad plural, el paradigma del "vivir bien", como también el bloque de constitucionalidad, fuente de garantía y parámetro indispensable para maximizar la protección de los derechos fundamentales, todo ello en el marco del nuevo modelo de Estado Plurinacional.

\footnotetext{
* Trabajo recibido el 19 de mayo de 2016 y aprobado el 5 de octubre de 2016.

Este trabajo fue presentado inicialmente al IV Congreso Latinoamericano de Derecho, organizado por el Instituto Latinoamericano de Derecho (con sede en Guayaquil-Ecuador), y que se realizó entre los días 18 al 20 de septiembre de 2014, en el Colegio de Abogados de la ciudad de La Paz (Bolivia). Posteriormente, el texto fue objeto de revisión, ampliando su contenido con mayores datos de jurisprudencia constitucional actualizada, para ser presentado en el VI Congreso Nacional de Derecho Penal, Derecho Civil y Derecho Constitucional, organizado por la Academia Boliviana de Ciencias Jurídico-Penales y el Centro Internacional para la Formación Superior, realizado los días 31 de julio y 1 de agosto de 2015, en el Auditorio del Ilustre Colegio de Abogados de la ciudad de La Paz-Bolivia.

** Abogado Especialista en Derecho Constitucional y Procedimientos Constitucionales (UMSA). Docente de la Universidad Privada Franz Tamayo (Unifranz), del Centro de Capacitación Municipal (CCaM) y de la Universidad Salesiana de Bolivia (USB). Autor de distintos libros sobre Derecho Constitucional, Derecho Procesal Constitucional y Derechos Humanos. Miembro de la Academia Boliviana de Estudios Constitucionales (www.abec.org.bo); del Instituto Iberoamericano de Derecho Procesal Constitucional-Sección Nacional (Bolivia), y Secretario Académico de la Asociación Boliviana de Derecho Procesal Constitucional. Abogado de la Dirección de Asesoría Legal del Gobierno Autónomo Municipal de La Paz. Responsable del Blog Jurídico: Tren Fugitivo Boliviano (http://alanvargas4784.blogspot.com/).
} 
ABSTRACT: On the occasion of the seventh anniversary of the Political Constitution of the Plurinational State of Bolivia, I consider pertinent to begin specifying what we understand by the word Constitution, its significance and scope Constitution rules, to then rescue the relevant jurisprudential development that have taken the principles of ethical-moral of our plural society, the paradigm of the "living well", as also the block of constitutionality, warranty and parameter to maximize the protection of fundamental rights all within the framework of the new model of Plurinational State.

Palabras Clave: Derechos fundamentales, Estado Plurinacional, Principios ético-morales, Vivir Bien, Bloque de constitucionalidad.

KEYWORDS: Fundamental rights, Plurinational State, Ethical-moral principles, Live Well, Constitutionality block.

\section{La Constitución y los Derechos fundamentales}

La Constitución -desde una perspectiva jurídica- es la Ley Suprema y Fundamental del ordenamiento jurídico del Estado, que consigna normas que regulan el sistema constitucional, lo que supone que debe proclamar los valores supremos $y$ principios fundamentales sobre los que se organiza y estructura el Estado; consagrando los derechos fundamentales y garantías constitucionales de las personas; delimitando la estructura social, económica, jurídica y política; definiendo su régimen de gobierno, junto al establecimiento de los órganos especificos a través de los cuales se ejercerá el poder político, determinando su estructura, organización y el ámbito de sus competencias.

La Constitución es Ley Suprema, porque se sitúa por encima de toda disposición legal que integra el ordenamiento jurídico del Estado, cuya validez está supeditada a las normas (axiológicas, dogmáticas y orgánicas), declaraciones y principios constitucionales; asimismo, es Ley Fundamental, porque tanto las disposiciones legales ordinarias emanadas del Órgano Legislativo, del Órgano Ejecutivo, así como de los órganos legislativos de los gobiernos autónomos y de todas las autoridades públicas, judiciales y/o administrativas tienen su fundamento y fuente de legitimación en las normas de la Constitución ${ }^{1}$.

Por otro lado, desde una perspectiva política, la Constitución se puede definir como un pacto social y político adoptado por el pueblo, en el cual se determina el sistema constitucional del Estado, estableciendo las reglas básicas para lograr una convivencia pacifica y la construcción de una sociedad democrática ${ }^{2}$, basada en los valores supremos, como ideales que una comunidad decide constituir como sus máximos objetivos a desarrollar por el ordenamiento jurídico y expresarlos en su estructura

\footnotetext{
1 Rivera (2006a), p. 44.

2 Rivera (2008), p. 8.
} 
social-económica-política; los principios fundamentales, como los presupuestos lógicos y líneas rectoras o básicas del sistema constitucional que orientan la política interna y externa del Estado; así como en los derechos fundamentales y garantías constitucionales de las personas, cuya garantía de cumplimiento y observancia constituye uno de los fines y funciones esenciales del Estado Plurinacional, que además tiene el deber de promoverlos, protegerlos y respetarlos ${ }^{3}$.

Sobre este aspecto es útil recordar que, a tiempo de precisar la naturaleza jurídica de los derechos fundamentales, la Sentencia Constitucional No 400/2006-R, de fecha 25 de abril de 2006, señaló que:

"Los derechos fundamentales son todos aquellos derechos subjetivos que corresponden universalmente a todos los seres humanos por su status de personas, de ciudadanos o personas con capacidad de obrar; entendiendo por derecho subjetivo cualquier expectativa positiva (de prestaciones) o negativa (de no sufrir lesiones) adscrita a un sujeto por una norma jurídica, en ese entendido, una de las notas caracterizadoras de todo derecho fundamental es el de ser un derecho subjetivo, lo que implica que su titular tiene la facultad de exigir su respeto y observancia, pudiendo acudir al órgano jurisdiccional competente para reclamar, a través de los recursos que establece el respectivo orden jurídico, la protección de tales derechos y la reparación del menoscabo sufrido.

Debe agregarse que según la doctrina contemporánea del Derecho Constitucional, los derechos fundamentales constituyen el límite al ejercicio del poder político del Estado, pero también un mecanismo de realización del propio Estado; por ello, se sostiene que los derechos fundamentales no incluyen sólo derechos subjetivos y garantías constitucionales a través de los cuales el individuo se defiende frente a las actuaciones de las autoridades públicas, también incluyen deberes positivos que vinculan a todas las ramas del poder público. En ese criterio, no sólo existe la obligación negativa por parte del Estado de no lesionar la esfera individual, también existe la obligación positiva de contribuir a la

3 Algunos autores estiman que la expresión, “derechos humanos" o derechos del hombre, llamados clásicamente derechos naturales, y actualmente derechos morales, no son en realidad auténticos derechos protegidos mediante acción procesal ante un juez, sino criterios morales de especial relevancia para la convivencia humana y que, en todo caso, una vez que determinados derechos humanos se positivizan, adquieren la categoría de verdaderos derechos protegidos procesalmente, transformándose en derechos fundamentales vigentes en un determinado ordenamiento jurídico, lo que equivale a decir que los derechos fundamentales son derechos humanos positivados por la legislación interna de un determinado Estado. En otras palabras, lo anterior significa que bajo la expresión "derechos fundamentales" se designa a los derechos garantizados y reconocidos por la Constitución y, en cambio, la denominación "derechos humanos" hace referencia a los derechos proclamados y garantizados por las normas e instrumentos internacionales; los primeros tienen como fuente de producción al legislador constituyente, y los segundos, a los Estados y organismos internacionales. DURÁN (2005), pp. 99-100. 
realización efectiva de tales derechos. Respecto a esta temática el Tribunal Constitucional de España, en su Sentencia STC 25/1981, estableció que: 'en primer lugar, los derechos fundamentales son derechos subjetivos, derechos de los individuos no sólo en cuanto derechos de los ciudadanos en sentido estricto, sino en cuanto garantizan un status jurídico o la libertad en un ámbito de existencia. Pero al propio tiempo, son elementos esenciales de un ordenamiento objetivo de la comunidad, en cuanto ésta se configura como marco de una convivencia humana justa y pacifica, plasmada históricamente en el Estado de Derecho y, más tarde en el Estado social de Derecho o el Estado social y democrático de Derecho, según la fórmula de nuestra Constitución”".

Por su parte, la Sentencia Constitucional No 1127/2003-R, de 12 de agosto, (al igual que en las SSCC 1181/2003-R, 1144/2003-R, entre otras) estableció que: "una de las notas que caracteriza a todo derecho fundamental, es la de tener la calidad de derecho subjetivo, que faculta a su titular a acudir al órgano jurisdiccional competente, cuando funcionarios públicos o particulares restrinjan, supriman o amenacen restringir o suprimir tales derechos. En nuestro pais, el legislador constituyente ha instituido el recurso de amparo como un medio de tutela para la eficaz salvaguarda de estos derechos, los cuales, desde un punto de vista moral y politico se consideran básicos para la convivencia humana, creando a su fragua las condiciones necesarias para asegurar el desarrollo de la vida del hombre en libertad, en circunstancias compatibles con la dignidad humana, legitimando y limitando el poder estatal, creando asi un marco de convivencia propicio para el desarrollo libre de la personalidad".

Asimismo, cabe recordar que la jurisprudencia constitucional, conforme las normas previstas en la Constitución así como en los tratados, convenciones y convenios internacionales suscritos y ratificados por el Estado boliviano, ha asumido que el ejercicio de los derechos fundamentales tiene límites, en consecuencia, las personas no pueden hacer un ejercicio absoluto o arbitrario que lesione los derechos de las otras personas o los intereses generales; así, en las Sentencias Constitucionales que se detallan a continuación, el Tribunal ha expresado los siguientes razonamientos:

- SC 04/2001 de 5 de enero:

“... los derechos fundamentales no son absolutos, encuentran límites y restricciones en los derechos de los demás, la prevalencia del interés general, la primacía del orden jurídico $y$ los factores de seguridad, moralidad y salubridad públicos, que no pueden verse sacrificados en aras de un ejercicio arbitrario o abusivo de las prerrogativas individuales; es decir, que los derechos fundamentales pueden ser limitados en función del interés social. Es en ese orden que la Constitución ha establecido el mecanismo legal para la regulación y restricción de los derechos fundamentales". 
- SC 429/2002-R de 15 de abril:

“... el art. 28 de la Declaración Americana de los Derechos y Deberes del Hombre dispone que: los derechos de cada hombre están limitados por los derechos de los demás, por la seguridad de todos y por las justas exigencias del bienestar general y del desenvolvimiento democrático'. Esto significa que las personas no pueden ejercer de manera irrestricta $y$ arbitraria sus derechos en desmedro de los derechos de los demás, por lo que su ejercicio debe estar reglamentado, conforme lo dispone la propia Constitución en su art. 7".

La referida jurisprudencia-conforme lo reconoció la SC 0061/2003, de 1 de julio, entre otras- tiene su fundamento en el hecho de que, tanto la Constitución como los instrumentos internacionales de protección de los derechos humanos que forman parte del bloque de constitucionalidad, no se limitan a proclamar el conjunto de los derechos, libertades y garantías de los seres humanos, sino que también hacen referencia explícita o implícita de las restricciones o limitaciones de su ejercicio, estableciendo, en su caso, las condiciones particulares en las cuales es posible que el Estado, a través de sus órganos del Poder Público, aplique la restricción al ejercicio de los derechos y libertades sin violarlos ${ }^{4}$. (Cfr. Sentencia Constitucional Plurinacional 0336/2012, de fecha 18 de junio de 2012).

\section{La CONSTITUCIÓN NORMATIVA Y SU APLICACIÓN DIRECTA}

Por otro lado, también se debe resaltar que en el caso de Bolivia la Constitución es Normativa ${ }^{5}$, vale decir, que se trata de la norma jurídica suprema que siendo la

4 Es en ese marco que la Constitución abrogada, además de proclamar el catálogo de los derechos fundamentales, establecía los límites a su ejercicio; en algunos casos de manera expresa, como, por ejemplo, en el referido a los derechos a la industria, el comercio y el trabajo (art. 7.d) CPE abrogada), o en el referido al derecho a la propiedad privada (art. 7.i) CPE abrogada); en otros, de manera implícita remitiendo a la ley. Se entiende que, como lo definió la Corte Interamericana de los Derechos Humanos en su Opinión Consultiva No C-06/86, "los fines para los cuales se establece la restricción deben ser legítimos, es decir, que obedezcan a 'razones de interés general' y no se aparten del 'propósito para el cual han sido establecidas'; de manera que las restricciones o limitaciones no eliminen el núcleo esencial de los derechos fundamentales ni se conviertan en un acto de supresión". Tribunal Constitucional de Bolivia, Sentencia Constitucional No 0019/2003, de 28 febrero de 2003.

5 El carácter normativo de la Ley Fundamental fue puesto de relieve por el Tribunal Constitucional Español, que en su momento señaló que la Constitución es una norma, pero una norma cualitativamente distinta de las demás, por cuanto incorpora el sistema de valores esenciales que ha de constituir el orden de convivencia política y de informar todo el ordenamiento jurídico. Tribunal Constitucional de España, Sentencias de 31 de marzo de 1981 y de 28 de abril de 1982, disponibles en: http://www.tribunalconstitucional.es/es/ Paginas/Home.aspx. 


\section{base del ordenamiento jurídico ${ }^{6}$, tiene preferencia en su aplicación por parte de} todas las autoridades y particulares, quienes se encuentran obligados a su observancia, y contiene un conjunto de principios fundamentales, valores supremos, derechos y garantías constitucionales que, en consonancia con los instrumentos internacionales sobre derechos humanos, conforman el bloque de constitucionalidad, y que son de aplicación directa para la resolución de conflictos concretos,

6 En el caso de Bolivia, de acuerdo al artículo 410 de la CPE, la Constitución adquiere la facultad de regular la vida jurídica, conformándose en el orden jurídico fundamental de la comunidad política; siendo que la Constitución se constituye como una norma jurídica fundamental y jerárquicamente superior a cualquier otra, es en este sentido que todo presupuesto necesario para el cumplimiento de sus disposiciones nace de ella misma como un acto del poder soberano. Por tanto, el precepto constitucional vincula a la sociedad política, incluyendo en ello a los poderes públicos. De esta manera, la Constitución debe entenderse como el marco en el que todos los actos del poder público deben tener cabida y encontrar fundamento y sus actos encuadrarse al texto constitucional, no debiendo vulnerarlo. Así, una función esencial de la jerarquía constitucional es la propia preservación de la Constitución Política del Estado como norma fundamental, por ello es necesario dotar de mecanismos de control que puedan preservar las facultades que el soberano plasmó en el texto constitucional, en especial frente a los actos de poder que puedan vulnerar su contenido, más aún si de vulneración de derechos fundamentales se trata. Por ello, una verdadera Constitución normativa y jerárquica, que se precie de ser la cúspide del ordenamiento jurídico de una comunidad política y que goza de la primacía o supremacía sobre las demás normas, debe prever mecanismos eficaces para reparar las posibles violaciones a

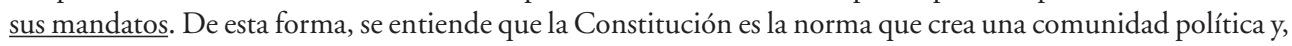
en ese sentido, es entendida como el fundamento del ordenamiento jurídico. Así, la Constitución se convierte en el punto de llegada de un proceso político y el punto de partida de un ordenamiento jurídico. Por ello, es a la Constitución a quien le corresponde la primacía respecto de todo el restante derecho interno. Por eso también el texto constitucional no puede ser derogado ni reformado por leyes ordinarias; y ninguna disposición del ordenamiento jurídico ni acto estatal alguno pueden contradecirla en cumplimiento del art. 410 de la CPE. Tribunal Constitucional de Bolivia, Sentencia Constitucional No 0019/2010-R, de 13 de abril de 2010. (Linea jurisprudencial sobre la eficacia plena y operatividad de la Constitución Política del Estado en el tiempo, reiterada posteriormente en varias sentencias de la gestión 2010). Entonces, la supremacía de la Constitución normativa que fundamenta la validez de todo el sistema jurídico plural de normas que la integra (art. 410.II de la CPE), no es per se (un mero asunto de jerarquías y competencias-pertenencia formal), sino porque está cargada de normas constitucionales-principios que son los valores, principios, derechos y garantías plurales que coexisten, que conviven como expresión de su "base material pluralista" y se comunican entre sí como expresión de su "base intercultural" y son los que informan el orden constitucional y legal, sin renunciar a su contenido de unidad (art. 2 de la CPE). De ahí que la Constitución de 2009, si bien es norma jurídica, no puede ser comprendida únicamente sólo de manera formal. Esto significa que no puede ser concebida sólo como un conjunto de normas (modelo descriptivo de Constitución como norma), a partir de un "concepto de Constitución (como norma) simplemente documental", con las denominaciones de "constitución formal" o incluso de "constitución en sentido formal", cuya primacía simplemente se sustente y esté distinguida de las otras leyes por alguna característica formal (por ejemplo, los procedimientos más complicados de producción, revisión y derogación). Por cuanto, lo que esencialmente diferencia a las normas constitucionales de las otras leyes, es que las primeras son prevalentemente normas constitucionales-principios (entiéndase por ello a la pluralidad de valores supremos, principios constitucionales, derechos fundamentales y garantías constitucionales) y supletoriamente normas constitucionales-reglas. Tribunal Constitucional Plurinacional, Sentencia Constitucional Plurinacional No 0112/2012, de fecha 27 de abril de 2012. 
emergentes de la tensión que pudiera surgir entre el Estado y los particulares, o inclusive de éstos entre sí.

Entonces, la Constitución, en la medida que contiene normas jurídicas de aplicación directa y de cumplimiento obligatorio, es una de las fuentes indispensables del Derecho en general, y del Derecho Constitucional en particular, constituyéndose en la base y fundamento de todo el ordenamiento jurídico, dado que incluye las normas fundamentales que estructuran el sistema jurídico y que actúan como parámetro indispensable de validez formal (de procedimiento), y material (de contenido), de todo el orden normativo del Estado.

En cuanto a la aplicación de directa de la Constitución Normativa, el Tribunal Constitucional Plurinacional, a través de la Sentencia Constitucional Plurinacional No 1357/2013, de 16 de agosto, ha dejado establecido que:

"La declaración de Estado Constitucional de Derecho se sustenta fundamentalmente en la necesidad de asumir que la Constitución Politica del Estado se erige como la norma fundamental del pais, cuya consecuencia inmediata no es otra, que impulsar y materializar en la realidad jurídica su carácter normativo; de modo que sus efectos trasciendan la totalidad del ordenamiento jurídico, bajo la condición de prevalecer sobre las demás normas infraconstitucionales y supeditar los procesos de interpretación normativa al contenido constitucional. La Constitución dejó, entonces, de ser aquella norma meramente programática, que sólo definió las competencias de los órganos del Estado y representó únicamente programas políticos que serian desarrollados por los órganos instituidos; para convertirse en Constitución normativa, cuyo efecto es su institución como norma suprema del ordenamiento jurídico que goza de primacía frente a cualquier otra disposición normativa (art. 410.II de la CPE).

Por tanto, como norma jurídica plena, es posible su aplicación directa por la generalidad de operadores jurídicos en la medida en que se reúnan los presupuestos para tal fin (art. 410.I de la CPE). En ese sentido, es congruente con la propia naturaleza y competencias del Organo Judicial, que esta aplicación directa de la Constitución encuentre mayor actividad en la función de administración de justicia por parte de jueces y tribunales; esto involucra que la generalidad de autoridades judiciales, y por qué no la de operadores jurídicos, deben ejecutar cualquier proceso de aplicación normativa considerando que su razonamiento debe iniciar precisamente por la interpretación y aplicación de la norma fundamental".

A esto se debe agregar que el art. 109 de la CPE determina que: "Todos los derechos reconocidos en la Constitución son directamente aplicables y gozan de iguales garantías para su protección". Por lo que es posible extraer que la vigencia de un Estado constitucional en el que deben prevalecer los derechos y garantías de las 
personas, involucra el deber de todo ciudadano de respetar la Constitución y procurar su materialización jurídica en la realidad social; puesto que una actitud en contrario restaría valor normativo a la Constitución y a los derechos que en ella se plasman, cuando más bien la virtud de un Estado Constitucional debe constituirse en la procura constante de su aplicación; siendo que dicha norma fundamental reúne los valores primarios que nuestra sociedad pactó a efecto de que se efectivicen en todos los ámbitos de la vida social y privada de las personas e instituciones.

Así, el constituyente no olvidó en imponer como deberes el conocimiento y cumplimiento de la Constitución y las leyes, y el respeto y promoción de los derechos reconocidos en la norma fundamental (art. 108.1).2) de la Constitución). Obligación que se profundiza respecto a las servidoras y servidores públicos, cuya actuación debe enmarcarse estrictamente bajo el principio de jerarquía normativa, al respeto de la Constitución, la ley y los derechos de las personas; siendo que dicha premisa se configura como el principal de los límites al ejercicio del poder público.

Ello guarda, como inmediata consecuencia, que las servidoras y servidores públicos tienen como primordial deber la sujeción de sus actos primeramente a la Constitución, y ante una evidente y notoria situación de vulneración o violación de la misma, tienen el deber de denunciar y asumir los actos que restablezcan dicho escenario dentro el marco de los supuestos jurídicos determinados por nuestro ordenamiento. Más aún, si se trata de una flagrante violación de derechos y garantías en total contravención a la Constitución y las leyes; en cuyo caso podrá asumirse medidas directas para la restitución de los derechos conculcados, siempre que ello no involucre la usurpación de funciones y suponga la reposición de un derecho que se halle vulnerado en notoria contradicción a la Constitución y las leyes. (Cfr. Sentencia Constitucional Plurinacional No 0828/2014, de fecha 30 de abril de 2014).

\section{El nuevo modelo de Estado Plurinacional Y EL DESARRollo JURISPRUdenCIAL DE LOS PRINCIPIOS ÉTICO-MORALES}

En cuanto se refiere al nuevo diseño constitucional del Estado Plurinacional Comunitario ${ }^{7}$ en Bolivia, cabe señalar que el artículo $1^{\circ}$ de la Constitución Política

7 Tribunal Constitucional Plurinacional, Sentencia Constitucional Plurinacional No 0957/2013, de 27 de junio de 2013. 
del Estado, aprobada el año 2009, sostiene que: "Bolivia se constituye en un Estado Unitario Social de Derecho Plurinacional Comunitario", un modelo de Estado que fue el resultado de la fuerza descolonizadora de los pueblos indígenas originarios campesinos, quienes plantearon el reto histórico de dar fin al colonialismo, con sujetos políticos colectivos con derecho a definir su destino, gobernarse en autonomías y participar en los nuevos pactos de Estado.

Ciertamente, este nuevo modelo de Estado tiene una inspiración anticolonialista que rompe con la herencia del constitucionalismo monocultural, que nació a espaldas de los pueblos indígenas, y del constitucionalismo pluricultural que introdujo de manera subordinada un reconocimiento parcial a los derechos de los pueblos indígenas. Así, nuestra Constitución marca una ruptura respecto al constitucionalismo clásico y occidental concebido por las élites políticas; es un constitucionalismo que expresa la voluntad de las clases populares y los pueblos indígenas, creando una nueva institucionalidad, transversalizada por lo plurinacional, una nueva territorialidad, signada por las autonomias, un nuevo régimen político y una nueva legalidad bajo el paradigma del pluralismo jurídico igualitario en el marco de la Constitución Política del Estado.

$\mathrm{Y}$ es que, efectivamente, nuestra Constitución tiene características que la distinguen e individualizan y dan cuenta de un constitucionalismo que no tiene precedentes (al menos en Latinoamérica), y cuyos intérpretes deben ser fieles a sus fundamentos, a los principios y valores que consagra, con la finalidad de materializar y dar vida a las normas constitucionales, siendo sus características más importantes la plurinacionalidad, la descolonización, el pluralismo jurídico igualitario, la interculturalidad y el vivir bien.

Al respecto, cabe señalar también que la Sentencia Constitucional Plurinacional No 0790/2012, de 20 de agosto, señaló entre sus fundamentos lo siguiente:

"El Estado Plurinacional Comunitario, como resultado de la fuerza descolonizadora de los pueblos indigenas originarios campesinos, ha hecho posible la visibilización de éstos, antes excluidos de toda institucionalidad estatal, reconociéndolos como naciones de pleno derecho junto a la antigua 'Nación Única'; por lo que dentro de esta concepción de Estado Plurinacional Comunitario, la comprensión de los derechos, deberes y garantías no puede realizarse desde la óptica del constitucionalismo liberal, sino más bien abrirse a una pluralidad de fuentes del derecho y de derechos, trascendiendo el modelo de Estado liberal y monocultural cimentado en el ciudadano individual, entendiendo que los derechos en general, son derechos de colectividades que se ejercen individualmente, socialmente y/o colectivamente, lo cual no supone la negación de 
los derechos y garantías individuales, pues el enfoque plurinacional permite concebir a los derechos, primero, como derechos de colectividades, luego como derechos que se ejercen individualmente, socialmente y colectivamente en cada una de las comunidades civilizatorias, luego como una necesidad de construir, de crear una comunidad de comunidades; es decir, un derecho de colectividades, un derecho que necesariamente quiebre la centralidad de una cultura sobre las otras y posibilite diálogos, espacios politicos de querella discursiva para la generación histórica y necesaria de esta comunidad de comunidades de derechos.

El reconocimiento y adopción del pluralismo jurídico hace posible un diálogo intercultural entre derechos, pues ya no existe una sola fuente de Derecho y de los derechos; de donde éstos pueden ser interpretados interculturalmente, lo cual habilita el carácter dúctil y poroso de los derechos, permitiendo un giro en la comprensión de los mismos, generando su transformación para concebirlos como práctica de diálogo entre culturas, entre mundos civilizatorios, en búsqueda de resignificar constantemente el contenido de los derechos para cada caso concreto.

Por ello, la construcción de la institucionalidad plurinacional parte del desmontaje de las lógicas de colonialidad, desmistificando la idea de que impartir justicia es solamente una 'potestad'; sino por el contrario, asumirla como un servicio al pueblo, concebida como facultadlobligación, pues fruto de la colonialidad antes construida, se ha estructurado una 'administración de justicia' extremadamente formal, cuasi sacramental, reproductora de prácticas judiciales desde la colonia y el periodo republicano, fundadas en la señorialidad de esta actividad bajo la concepción de 'potestad' antes que de 'servicio', sustentado por todo un aparato normativo, doctrinal e institucional. Corresponde al Tribunal Constitucional Plurinacional, romper esas relaciones y prácticas que se reproducen en lo social, cultural, politico e institucional, constituyéndose en un instrumento destinado a la generación de espacios de diálogo y relacionamiento de las diferentes concepciones jurídicas en el marco del Estado Plurinacional Comunitario, aportando al proceso de interpretación intercultural de los derechos humanos y fundamentales, asi como de las garantías constitucionales, con énfasis en los derechos colectivos y de las naciones y pueblos indigenas originarios campesinos".

Actualmente, la Constitución Política del Estado, además de declarar que Bolivia se constituye en un Estado Unitario Social de Derecho Plurinacional Comunitario, libre, independiente, soberano, democrático, intercultural, descentralizado y con autonomías, dedica su Capítulo Segundo a establecer expresamente los Principios, Valores y Fines del Estado, a cuyo efecto el artículo 8 constitucional declara que el Estado Plurinacional de Bolivia asume y promueve como principios ético-morales de la sociedad plural: 
"ama qhilla", ama llulla", ama suwa (no seas flojo, no seas mentiroso ni seas ladrón), suma qamaña (vivir bien), ñandereko (vida armoniosa), teko kavi (vida buena), ivi maraei (tierra sin mal) y qhapaj ñan (camino o vida noble)"; y asimismo señala que nuestro Estado "se sustenta en los valores de unidad, igualdad, inclusión, dignidad, libertad, solidaridad, reciprocidad, respeto, complementariedad, armonía, transparencia, equilibrio, igualdad de oportunidades, equidad social y de género en la participación, bienestar común, responsabilidad, justicia social, distribución y redistribución de los productos y bienes sociales, para vivir bien".

8 Este Principio ético-moral, también ha sido desarrollado a nivel jurisprudencial, en cuanto a su relevancia para la pronta resolución de los procesos penales; así, la Sentencia Constitucional Plurinacional No 0110/2012, de fecha 27 de abril de 2012, estableció: "Cabe señalar además, que el Estado Plurinacional de Bolivia, al tenor del art. I de la CPE, se funda en la pluralidad y el pluralismo político, económico, jurídico, lingüístico y ante todo cultural, respetando y reafirmando los valores ético-morales de nuestra cultura ancestral, tal como el 'ama qhilla', palabra quechua que traducida al español significa 'no seas flojo' y, es por ello que nuestra Norma Fundamental en su art. 8, la constitucionaliza como principio, al igual que el 'Ama llulla' (no seas mentiroso) y 'Ama Suwa' (no seas ladrón), con la intencionalidad de que la población encuentre en el trabajo y en el cumplimiento del deber una grata y satisfactoria labor, tal como lo conceptuaron nuestros antepasados y las actuales culturas que sancionan con severas medidas su infracción, en tanto que nuestra Ley del Órgano Judicial, en su art. 128, determina que el juez es pasible de enjuiciamiento disciplinario por incurrir en demora culpable cuando éste dicta resoluciones en los procesos fuera de los plazos fijados por la ley, tal como acontece en el caso presente, más aún cuando la solicitud corriente a fs. 2, está vinculada al restablecimiento de un derecho fundamental cual es la libertad del detenido. En consecuencia los operadores de justicia tienen la obligación de respetar y cumplir con la precitada norma constitucional y, solo bajo ésta línea jurisprudencial ya establecida en la SC 0015/2012-R de 16 de marzo de 2012, los jueces y tribunales deben dirigir y resolver los casos sometidos a su conocimiento dentro de los plazos previstos por ley y, para el caso de no estar normados, desarrollar los actuados procesales dentro de un término razonable, por cuanto sus dilaciones indebidas y retardaciones injustificadas, atentaran los derechos fundamentales de las partes que van exigiendo mayor celeridad en la tramitación de sus causas".

9 Sobre la relevancia de este principio ético moral, y su relación directa con la temeridad o malicia con que muchas veces actúan las partes en el proceso, la Sentencia Constitucional Plurinacional No 1240/2013, de fecha 1 de agosto de 2013, precisó el siguiente entendimiento: “(...) Atendiendo todo lo expuesto, es posible concluir que mientras, la razón de orden procesal para la denegatoria de una acción de amparo cuando existe identidad de: (1) Partes procesales, referidas a la legitimación activa y legitimación pasiva; y, (2) Problema jurídico en los que se funda la demanda con otra acción de amparo anteriormente interpuesta y resuelta, es la existencia de cosa juzgada constitucional (art. 203 de la CPE); la razón de orden ético moral, que justifica la imposición de multa a la o el accionante cuando su acción es denegada por la causal señalada, es el ama llulla (no mientas) principio ético moral, que junto a los otros de la sociedad plural previsto en el art. 8.I de la CPE, conforme entendió la SC 0112/2012 de 27 de abril, imponen a todos, esto es, al poder público y los particulares en la convivencia social, con mayor razón a todos los jueces de la pluralidad de jurisdicciones, la obligación de observarlos, desarrollarlos y aplicarlos en su labor decisoria cotidiana'. Esto, debido a que el accionante (legitimado activo) a sabiendas de que la justicia constitucional resolvió su problema jurídico, insiste a esta jurisdicción, con otra demanda, pretendiendo sorprender a este órgano jurisdiccional. Es lo que la doctrina procesal constitucional denomina temeridad, siendo temeraria la interposición de una acción de amparo cuando se hace un uso abusivo del mecanismo de defensa de los derechos fundamentales, pese a que la acción es abiertamente improcedente". 
Aquellas máximas milenarias: Ama Quilla, Ama Llulla, Ama Suwa (no seas flojo, no seas mentiroso ni seas ladrón), han sido establecidas como principios ético-morales por el constituyente, y conforme puntualizó la Sentencia Constitucional Plurinacional No 0015/2012 de 16 de marzo: “...resumen de manera extraordinaria la moral que toda persona, natural o jurídica debe practicar en todas sus actividades. En ese sentido, se hace énfasis en el principio del ama qhilla, que establece una conducta de vida diligente que debe observar todo individuo, con mayor razón un servidor público como es el juez, del cual debe exigirse una actitud acuciosa en la administración de justicia, sobre todo cuando afecta a un vivir bien, asi como a una vida armoniosa. (...), siendo responsables de cualquier demora por su inactividad, impulsando la nueva justicia en el nuevo Estado Plurinacional".

En este sentido, cabe tener presente -conforme lo ha precisado la Sentencia Constitucional Plurinacional No 0951/2012, de 22 de agosto- que el Estado Unitario Social de Derecho Plurinacional Comunitario asume y promueve los principios ancestrales pertenecientes a la cultura quechua-aymara, entre ellos: Ama quilla, Ama llulla, Ama suwa (no seas flojo, no seas mentiroso ni seas ladrón), en aymara: Jan jairamti, jan lonthatasimti, jan q'arimti, trilogía inseparable en su composición, no es posible comprender por separado; sin embargo, por la técnica jurídica individualizada "Ch'ulla", para aplicar al caso concreto, el TCP ha desarrollado la misma, de conformidad al Código Procesal Constitucional, cuyo art. 3.8 dispone que las Sentencias Constitucionales deben estar redactadas de forma sencilla y fácilmente comprensible para la sociedad.

En cumplimiento del principio de procedimiento constitucional citado, la referida Sentencia explica el significado y alcances del término: "Principio", entendido como un axioma que plasma una determinada valoración de justicia de una sociedad, sobre la que se construyen las instituciones del Derecho y que en un momento histórico determinado informa del contenido de las normas jurídicas de un Estado.

Un principio es un axioma que deriva del griego "axioma", que significa "lo que parece justo", originariamente significaba "dignidad" y por derivación se ha llamado "axioma" a "lo que es digno de ser estimado, creído o valorado"; así podemos entender que un principio es el pilar fundamental sobre el que se construyen valores que deben sostener a los derechos y garantías constitucionales.

El Estado boliviano asume para sí los "principios ético-morales"; es decir, hay la necesidad de comprender, el principio, la ética y la moral, que amerita comprensión mediante "ejes transversales" que se constituyen en una unidad indisoluble emergente de la "realidad", que sólo adquiere su verdadero significado 
en relación a otras piezas; por ello los principios están unidos a la ética y a la moral, constituyéndose en una unidad transversal.

La ética etimológicamente proviene del griego "ethos", que significa "forma de ser”, es una norma del fuero interno que impulsa el respeto humano, practicada de forma estamentaria en el conglomerado social.

Con referencia a la moral proviene del latín "mores", "modos habituales de obrar o proceder", principios de comportamiento en la vida privada, cuya base es la norma individual que se expresa en el comportamiento de cada uno en la sociedad que hace la diferencia.

En materia jurídica - dice la citada Sentencia- un principio no es una norma ni una garantía, es el fundamento y base imprescindible para la existencia de una garantía, por ello el Constituyente incorporó en la Constitución Política del Estado ocho principios que son rectores imperativos de nuestra sociedad, entre ellos tenemos: ama qhilla (no seas flojo); ama llulla (no seas mentiroso); ama suwa (no seas ladrón), se deben entender estos tres axiomas como una unidad inseparable; toda vez que la misma constituye una filosofía ancestral fundada en el "tricálogo complementario", cuya comprensión sería inútil al disgregarse; tampoco se debe olvidar de los otros principios como: suma qamaña (vivir bien), ñandereko (vida armoniosa), teko kavi (vida buena), ivi maraei (tierra sin mal), qhapaj ñan (camino o vida noble), que son principios de aplicación obligatoria para alcanzar el valor máximo que también es el vivir bien, o suma qamaña, "Vida en plenitud" en aymara, equilibrio material y espiritual del individuo, saber vivir y la relación armoniosa del mismo con todas las formas de existencia, "convivir".

Asimismo, y con referencia a la preservación de la unidad del mencionado "tricálogo", la citada Sentencia Constitucional Plurinacional No 0951/2012 realiza las siguientes consideraciones:

"El historiador Antonio Guevara en su libro Historia del Perú, Vol. 1 (págs. 172 a 173), dice: 'Pocos pueblos de la tierra han logrado el considerable adelanto moral que alcanzaron los hombres del antiguo Perú, en su sociedad estaban ausentes: el robo, los crimenes, la mentira, la ociosidad, la pobreza y la mendicidad; se distinguió por el espiritu laborioso de sus componentes, el respeto mutuo y el bienestar común'. 'Este extraordinario encumbramiento espiritual fue el resultado de sabias enseñanzas morales, de consejos y normas de conducta que el Estado habia convertido en leyes. El Código Moral de los Incas estuvo formado por dichas normas, especie de preceptos o mandatos divinos, cuyo cumplimiento era obligatorio para todos los habitantes del Imperio'. Y enfatiza: 'Entre tales preceptos morales los siguientes: Ama Llulla (No seas mentiroso); Ama Suwa (No seas ladrón) y Ama Quilla (No seas haragán). 
Se debe tener presente que la trilogía es un constructo filosófico de los antepasados; en este sentido, encuentra su explicación ponencial bajo el siguiente razonamiento; Ama Qhilla, no seas flojo, si eres haragán necesitarás robar para alimentarte (Ama Suwa), para justificar el robo de tus alimentos, necesitaras mentir, (Ama Llulla)'; explicación escueta, cuyo pensamiento filosófico implicaría la redacción de varias páginas; no obstante, a modo de adelantar su comprensión, describimos el pilar del Ama Suwa, cuyo alcance, no solamente hace referencia al robo patrimonial, como establece la norma ordinaria, el robo también en la cultura ancestral, tiene su alcance al aspecto inmaterial, por ejemplo, 'el robo del tiempo', cuando el interlocutor sin que exista un motivo fundado, causa perjuicio al otro laborioso, ha incurrido en el robo de su tiempo destinado a realizar una actividad especifica, a igual tiempo, no sólo le ha robado tiempo al otro, también se ha robado a si mismo, al haber desgastado su tiempo en actividades fútiles en horas de producción, entonces el Ama Suwa se debe comprender en un espectro amplio y no limitante; del mismo modo, Ama Llulla, no sea mentiroso, no mientas a los otros sobre tu realidad ni te mientas a ti mismo sobre tu propia realidad; en otras palabras, no se debe fingir estar bien, cuando lo correcto es decir la verdad sobre la realidad de otros y la tuya, que también es de todos; finalmente, el Ama Qhilla, la flojera, considerada como una enfermedad, no es natural que un hombre sano, tenga flojera, el ser humano por naturaleza es dinámico, realiza actividades desde que se despierta hasta que se duerme; consecuentemente, el no realizar una actividad productiva perjudica a su vida y a la vida de los demás, la responsabilidad tiene mayor trascendencia, cuando se trata de un servidor público, quien no solamente perjudica con su proceder ocioso, a su propio lugar de trabajo, sino también perjudica a los justiciables.

El efecto deseado de la aplicación del tricálogo en la administración de justicia es la justicia plural, pronta, oportuna, transparente, sin dilaciones, con honestidad, veracidad y laboriosidad que debe ser característica del servidor público, del ser humano y de los funcionarios en todos los niveles, estos tres principios fundamentan la garantía del vivir bien, esta trilogía normó la vida del hombre ancestral quechua aymara, y tiene hoy prevalente aplicación en la formación del tipo de hombre que busca modelar la Norma Suprema, desechando las prácticas coloniales según los alcances del art. 9 de la CPE, para constituir una sociedad justa y armoniosa, cimentada en la descolonización".

Finalmente, y en cuanto a la aplicación justificada del Ama Qhilla en la actividad de los servidores públicos y servidoras públicas, la mencionada Sentencia Constitucional Plurinacional No 0951/2012, estableciendo una línea jurisprudencial reiterada posteriormente en la Sentencia Constitucional Plurinacional No 0551/2014, de 10 de marzo, señaló lo siguiente:

"El Ama Quilla es la flojera, que se visibiliza en la dilación injustificada por parte de las servidoras o servidores públicos, quienes están en la obligación de dominar la pereza, de 
la cual emerge la conducta de dejar para mañana lo que se debe hacer hoy, este vicio es el gustito por la apatía e inacción física y moral que perjudica la actividad judicial que es dinámica, más aún cuando de por medio están los plazos, la preclusión, la retardación, entre otros perjuicios. Una manera de ser perezoso es cobrar sueldo sin trabajar, es frecuente observar las quejas de los servidores públicos, particularmente de los operadores de justicia, la desidia con la que atienden a los justiciables, acudiendo recurrentemente a la justificación de la demasiada carga procesal-argumento que no es válido a la luz de las últimas sentencias constitucionales-, falta de personal, y otras justificaciones banales, en muchos casos, hacen de la pereza una filosofia de vida, convirtiéndose sin saberlo, en seguidores de Epicuro, flósofo griego que predicaba la pereza como bien supremo y como ideal de vida. Muchos servidores públicos se convierten en Epicurianos, seguidores de ese sophista y su vergonzosa prédica, quieren vivir sin trabajar, a costa de un pueblo que trabaja para sostener un proceso, se preocup a y saca tiempo para anoticiarse del resultado de su memorial, cuando llega al juzgado se encuentra que todavía no fue despachado por la negligencia de algún servidor epicuriano.

Al insertar el Ama Qhilla en la Ley Fundamental, el Constituyente, pretendió luchar, entre otros objetivos, contra la retardación de justicia que tiene como causa, precisamente, la flojera, la negligencia, la desidia, a ellos va dirigido al Ama Qhilla, no seas flojo, a los fines de que los operadores de justicia despachen en el día los memoriales, remitan los actuados a la instancias correspondientes, notifiquen a las partes de oficio, etc., es necesaria la práctica de este principio, si queremos cambiar e ingresar a la justicia pronta para vivir bien. En Bolivia se han sentado las bases para materializar el Estado Constitucional de Derecho".

El desarrollo a nivel jurisprudencial de estas máximas milenarias se ha expresado a través de un importante pronunciamiento del Tribunal Constitucional Plurinacional, emitido en ocasión de verificar la constitucionalidad de un polémico Proyecto de Ley de Extinción de Dominio de Bienes a favor del Estado. Es así que la Declaración Constitucional No 002/2013, de fecha 19 de abril de 2013, ha dejado establecido el siguiente entendimiento:

“(...) En ese sentido, el ama qhilla, establece una valoración de lo justo por una sociedad dedicada diligentemente al trabajo y a una conducta de vida laboriosa, que debe observar todo individuo como filosofia de vida, descartando la flojera, la pereza o la desidia, tomando en cuenta que nuestros pueblos ancestrales concebian el trabajo, no como una carga o sacrificio, sino como un motivo de dicha y felicidad, orientado siempre a la buisqueda del bienestar común, por lo que ahora, en el Estado que nos proponemos construir, todos estamos moralmente compelidos a expulsar la flojera dentro de nuestros hábitos de vida y encontrar en el trabajo honrado, el único medio para proveer a nuestro sustento y para crear riqueza lícita, todo lo cual, desde una perspectiva moral, legitima al Estado 
la posibilidad jurídica de extinguir toda riqueza generada de manera ilícita y que no sea producto del trabajo honrado.

El ama lulla en cuanto a no ser mentiroso (...), se trasunta en el falseamiento de la realidad de quienes ostentan riqueza mal habida, en la impostura de los que detentan una propiedad que jurídicamente sólo es tal en apariencia, en el engaño fútil o la ignominia de la que se valen aquellos que pretenden acumular riqueza fácil a costa de la sociedad $y$ del Estado. (...) El ama suwa (no seas ladrón), que en su concepción amplia debe ser entendido como el mandato para actuar siempre con honestidad y transparencia, sin apropiarse ilegitimamente de lo ajeno, de aquello que pertenece a la comunidad y que sirve y beneficia a todos, respetando lo ajeno, no utilizando los bienes de la comunidad en beneficio propio, ideal ético de la sociedad plural que no puede consentir jamás la acumulación de riqueza ilícita proveniente del robo en su acepción más amplia, menos de actividades que (...), laceran profundamente la moral de la sociedad, ponen en zozobra la seguridad de sus ciudadanos, empobrecen económicamente al Estado, impiden $y$ dificultan su desarrollo, corrompen funcionarios y socavan sus instituciones, de donde el ama suwa como principio ético-moral que debe asumir y promover el Estado, sustenta constitucionalmente la posibilidad de que éste extinga el dominio sobre bienes de procedencia ilícita provenientes de actividades nefastas como el narcotráfico, contrabando, corrupción y legitimación de ganancias ilícitas".

Por otro lado, se ha establecido también la importancia de la estrecha relación entre la premisa milenaria del ama qhilla y el rasgo plurinacional del derecho al trabajo. En este sentido, según el TCP, el art. 1 de la CPE establece que el Estado Plurinacional de Bolivia se constituye en un Estado Unitario Social de Derecho Plurinacional Comunitario; modelo que no obstante poseer características que provienen del constitucionalismo liberal y social, tiene características propias que marcan el horizonte de un constitucionalismo plurinacional, comunitario y descolonizador, y que determinan que los principios y valores constitucionales, así como los diferentes derechos, garantías e institutos jurídicos que provienen de la lógica occidental sean reinterpretados a la luz de las nuevas características de nuestro modelo.

"En ese ámbito -según la citada Declaración Constitucional-, el derecho al trabajo, desde la dimensión plural que fundamenta nuestro Estado, tiene características sociales y comunitarias y, en ese sentido, debe ser entendido como el esfuerzo personal o comunitario que realiza el trabajador o trabajadores para la producción de bienes o servicios, lo cual requiere de esfuerzos fisicos o, en su caso, intelectuales de acuerdo a la naturaleza del trabajo. Ahora bien, el derecho al trabajo desde el nuevo enfoque plurinacional; es decir, desde los principios ético-morales de la sociedad plural, que son transversales e integrales en la vivencia de la comunidad y se proyectan hacia el vivir bien, se encuentra intima- 
mente vinculado con el ama quilla (prohibido ser flojo), que tiene una triple dimensión: como valor, principio y norma, y que se practica en la comunidad milenariamente, con la finalidad que sus miembros sean laboriosos y el trabajo sea visto como un motivo de felicidad y no asi como una carga, lo cual sería funesto desde el pensamiento de las comunidades milenarias; pues, la flojera implica no trabajar y, con ella se presentan los problemas emergentes, como el hambre, la miseria y otros males, entre ellos, la comisión de delitos; por ello es que el trabajo es altamente valorado, pues permite llevar una vida plena en comunidad y armonía, siendo por tanto deber de las autoridades garantizar la estabilidad laboral de los funcionarios.

Entonces, todo despido arbitrario o injustificado constituye desconocimiento al principio plurinacional ama quilla que materializa el ejercicio pleno del trabajo personal y comunitario; es decir, el trabajo en todas sus formas desarrollado desde el enfoque del derecho de nuestros pueblos milenarios, lo que implica la prohibición de despidos arbitrarios o injustificados de parte del empleador, existiendo más bien la obligación de garantizar la estabilidad laboral a la luz de los principios ético-morales de la sociedad plural, pues el trabajo proporciona una retribución económica, que constituye el elemento fundamental para el sustento de la persona, la familia o la comunidad; por ello, se debe fortalecer progresivamente la tendencia a defender al trabajador por parte del Estado a través de las leyes y mecanismos pertinentes. Asi, el art. 46.I de la CPE, establece que toda persona tiene derecho al trabajo digno, con seguridad industrial, higiene y salud ocupacional, sin discriminación, y con remuneración o salario justo, equitativo y satisfactorio, que le asegure para si y su familia una existencia digna; y el parágrafo II del mismo artículo, de manera expresa sostiene que el Estado protegerá el ejercicio del trabajo en todas sus formas; lo que implica que el Estado, a la luz del constitucionalismo plurinacional, comunitario $y$ descolonizador, debe proteger fundamentalmente a los trabajadores y a las trabajadoras de manera individual y/o colectiva, de forma eficiente ante despidos arbitrarios e injustificados de los que puedan ser objeto". (Cfr. Sentencia Constitucional Plurinacional No 1511/2013, de fecha 30 de agosto de 2013. El subrayado me corresponde).

En esa línea, el Tribunal Constitucional Plurinacional, en la Sentencia Constitucional Plurinacional No 2619/2012 de 21 de diciembre, estableció también lo siguiente:

“(...) la estructura normativa en sus diferentes ámbitos está dirigida en lo fundamental a proteger a las trabajadoras y trabajadores del país contra el despedido arbitrario del empleador sin que medie circunstancias atribuidas a su conducta o desempeño laboral, que de acuerdo a nuestra legislación se las denomina causas legales de retiro, prevaleciendo el principio de la continuidad de la relación laboral, viabilizando la reincorporación de la trabajadora o trabajador a su fuente de trabajo o el pago de una indemnización, conforme nuestra legislación vigente. Es decir, entre la estabilidad absoluta y la estabilidad relativa. 
La primera entendida como el derecho del trabajador a reincorporarse a su fuente de trabajo cuando éste fue objeto de un despido intempestivo y sin una causa legal justificada y la segunda, como el derecho del trabajador a ser indemnizado por la ruptura injustificada de la relación laboral. A este objeto se crea un procedimiento administrativo sumarísimo otorgándole facultades al Ministerio de Trabajo Empleo y Previsión Social, para establecer si el retiro es justificado o no para luego proceder a una conminatoria de reincorporación y finalmente recurrir a la jurisdicción constitucional en caso de resistencia del empleador a su observancia, medida adoptada con el fin de garantizar el cumplimiento inmediato de un acto administrativo a través de la jurisdiccional constitucional cuyos fallos están revestidos por esta característica"'.

\section{El paradigma del "Vivir Bien" y su desarrollo juRisprudencial}

En cuanto se refiere a los alcances del paradigma del "vivir bien", conviene recordar que el preámbulo de la Constitución señala que la construcción del nuevo Estado está basada en el respeto e igualdad entre todos, dentro de los alcances de los principios de complementariedad, solidaridad, armonía y equidad en la distribución y redistribución del producto social, donde predomine la búsqueda del vivir bien, con respeto a la pluralidad económica, social, jurídica, política y cultural de los habitantes de esta tierra y en convivencia colectiva con acceso al agua, trabajo, educación, salud y vivienda para todos.

Entonces, a partir de la concepción del pluralismo como elemento fundante del Estado, el modelo de Estado se estructura sobre la base de derechos individuales y también derechos con incidencia colectiva, pero, además, la concepción del pluralismo y la interculturalidad configuran un diseño de valores rectores en mérito de los cuales se concibe una Constitución axiomática. En efecto, la Constitución aprobada en 2009 se caracteriza no solamente por su "valor normativo", sino esencialmente por su "valor axiomático", y esta característica tipifica a la Norma del Estado Plurinacional de Bolivia como una "Constitución Axiomática”, en mérito de la cual el fenómeno de constitucionalización del ordenamiento jurídico, es decir, el proceso de irradiación de contenido en las normas infraconstitucionales y en todos los actos de la vida social, no solamente comprende normas constitucionales positivizadas, sino también valores supremos directrices del orden constitucional.

En este contexto, el pluralismo y la interculturalidad constituyen los elementos de refundación del Estado Plurinacional de Bolivia, en mérito de los cuales el Valor Axiomático de la Constitución adquiere un matiz particular, ya que las directrices principistas y los valores plurales supremos en el Estado Plurinacional 
de Bolivia irradiarán de contenido a todos los actos infraconstitucionales, incluidas las decisiones de las autoridades indígena originario campesinas; además, en virtud al principio de complementariedad que postula la interculturalidad, estos valores plurales supremos irradiarán toda la vida social armonizando así las bases sociológicas de una sociedad plural, consolidando una verdadera cohesión y armonía social.

En efecto, el pluralismo como elemento fundante del Estado Plurinacional de Bolivia implica el reconocimiento de una pluriculturalidad y, por ende, un pluralismo axiomático, que postula valores plurales supremos insertos en el Preámbulo de la Constitución y también en su artículo 8.

Así, se puede destacar que entre los valores plurales supremos que guían al Estado Plurinacional de Bolivia, se encuentran la igualdad, la complementariedad, la solidaridad, reciprocidad, armonía, la inclusión, transparencia, igualdad de condiciones, bienestar común, responsabilidad, entre otros, los cuales, a su vez, en el marco de la interculturalidad, se complementan con los valores ético-morales plasmados en el art. 8.1 de la Constitución, como ser el ama qhilla, ama llulla, ama suwa (no seas flojo, no seas mentiroso ni seas ladrón); suma qamaña (vivir bien); el ñandereko (vida armoniosa); teko kavi (vida buena); ivi maraei (tierra sin mal) y qhapaj ñan (camino o vida noble), entre otros, los cuales, al encontrarse insertos en la parte dogmática de la Constitución, irradiarán de contenido a la inter-legalidad (concepto en virtud del cual se entiende que las fuentes jurídicas plurales son autónomas, pero interdependientes axiomáticamente en aplicación al principio de complementariedad, el cual a su vez encuentra razón de ser en la interculturalidad y el pluralismo como elementos fundantes del Estado), para consolidar así el valor esencial y fin primordial del Estado Plurinacional de Bolivia, que es el "vivir bien".

Por lo expuesto, y a la luz de la Constitución Axiomática desarrollada precedentemente, la Sentencia Constitucional Plurinacional No 1422/2012, de 24 de septiembre de 2012, ha fundamentado la importancia el paradigma del vivir bien, como pauta específica de interpretación intercultural de derechos fundamentales:

"En efecto, a la luz de los principios de interculturalidad, complementariedad y descolonización, los derechos fundamentales vigentes para los miembros de las naciones y pueblos indigena originario campesinos, no pueden seguir las mismas pautas de interpretación ni pueden contener los mismos elementos configurativos propios de los núcleos duros de derechos fundamentales en contextos diferentes a la jurisdicción indigena originario campesina. En esta perspectiva, el paradigma del vivir bien se configura como una verdadera pauta de interpretación inter e intracultural de derechos fundamentales, a partir de la cual, 
los valores plurales supremos irradian de contenido los actos y decisiones que emanan de la justicia indigena originaria campesina, constituyendo además una garantía plural destinada a evitar decisiones desproporcionadas y contrarias a las guias axiomáticas del Estado Plurinacional de Bolivia.

En el orden de ideas expresado, se tiene que el paradigma del vivir bien, somete a sus postulados a todas las decisiones emergentes del ejercicio de la jurisdicción indigena originario campesina, por lo que, en el supuesto de activarse el control tutelar de constitucionalidad a través de acciones de defensa como ser la acción de libertad, las decisiones de la jurisdicción indigena originaria campesina denunciadas como lesivas a derechos fundamentales en contextos interculturales, en el ejercicio del control plural de constitucionalidad, deberán analizarse en el marco de los siguientes parámetros de axiomaticidad proporcional y razonable propios del paradigma del vivir bien: a) armonía axiomática; b) decisión acorde con cosmovisión propia; c) ritualismos armónicos con procedimientos, normas tradicionalmente utilizados de acuerdo a la cosmovisión propia de cada nación y pueblo indígena originario campesina, y d) proporcionalidad y necesidad estricta". 10

10 "De acuerdo a lo señalado -continúa desarrollando la citada Sentencia-, se tiene que la armonía axiomática implica que toda decisión emanada de la jurisdicción indígena originario campesina, en cuanto a sus fines y medios empleados, asegure la materialización de valores plurales supremos como ser la igualdad, complementariedad, solidaridad, reciprocidad, armonía, inclusión, igualdad de condiciones, bienestar común, entre otros, en ese orden, el control plural de constitucionalidad, en caso de ejercer sus roles en relación a decisiones emanadas de la jurisdicción indígena originario campesina, para el análisis del primer elemento del test del paradigma del vivir bien, utilizará el método jurídico de la ponderación intercultural, a cuyo efecto, a la luz de los valores plurales supremos antes descritos, deberá cotejar los fines perseguidos por la decisión en relación a los medios empleados, para luego verificar la armonía de los fines y medios utilizados en la decisión con los valores plurales supremos descritos precedentemente, evitando así una discordancia con los postulados de la Constitución axiomática. En coherencia con lo señalado, debe establecerse que el control plural de Constitucionalidad, en su labor plural hermenéutica, como segundo elemento del test del paradigma del vivir bien, deberá, a través de la metodología de la ponderación intracultural, cotejar la armonía y concordancia de la decisión emanada del pueblo o nación indígena originario campesino con su propia cosmovisión, a cuyo efecto, la cosmovisión de cada pueblo o nación indígena originario campesino, debe ser entendida como la concepción que la nación o pueblo indígena originario campesino tenga sobre su realidad cultural de acuerdo a sus valores y cultura propia. Asimismo, se establece que para el tercer elemento del test del paradigma del vivir bien, el control plural de constitucionalidad, deberá verificar que la decisión emanada de la jurisdicción indígena originaria campesina sea acorde con los ritualismos armónicos con procedimientos, normas tradicionalmente utilizados por la comunidad, de acuerdo a la cosmovisión propia de cada nación y pueblo indígena originario campesino. Como cuarto elemento del test del paradigma del vivir bien, el control plural de constitucionalidad, deberá establecer la proporcionalidad de la decisión asumida por la jurisdicción indígena originario campesina, en este caso, se deberá ponderar la naturaleza y gravedad de los hechos plasmados en la decisión en relación con la magnitud de la sanción impuesta. Además, en este análisis de proporcionalidad, para sanciones graves, deberá también ponderarse la decisión asumida en relación a la estricta necesidad de la misma, es 
Posteriormente, y considerando la importancia de fundamentar el paradigma del vivir bien, como pauta especifica de interpretación intercultural de derechos fundamentales (según lo desarrollado por la SCP 1422/2012), cabe señalar que la Sentencia Constitucional Plurinacional No 0778/2014, de 21 de abril de 2014, en base a una interpretación evolutiva, ha complementado y redimensionado dicha pauta de interpretación, en el siguiente sentido:

"El paradigma del vivir bien, como pauta de interpretación intercultural para la tutela de derechos individuales o colectivos en contextos inter e intraculturales, establece parámetros de carácter general acordes con el nuevo modelo de Estado y en particular con el pluralismo la interculturalidad y la descolonización para que a través del control de constitucionalidad, en cada caso concreto, se asegure una real materialización del vivir bien y de sus valores constitutivos como ser la complementariedad, equilibrio, dualidad y armonía, entre otros, en ese orden, dichos parámetros a ser analizados en el marco de un diálogo intercultural componen de manera general los siguientes aspectos:

i) El análisis de compatibilidad del acto o decisión cuestionado con las normas y procedimientos propios de cada nación y pueblo indígena originario campesino, aspecto que obliga tanto a los jueces o tribunales de garantías, como al Tribunal Constitucional Plurinacional, a resolver la problemática, de acuerdo a métodos y procedimientos constitucionales interculturales, como ser los peritajes antropológico-culturales o el desarrollo de diálogos en las propias comunidades, para que en caso de verificarse una incompatibilidad de dichas normas y procedimientos, se materialice el valor del vivir bien, el cual es el contenido esencial de los derechos individuales o colectivos en contextos intra e interculturales, $y$

ii) El análisis de compatibilidad del acto o decisión cuestionado con los principios de complementariedad, equilibrio, dualidad, armonía y otros de la cosmovisión propia de los pueblos y naciones indigena originario campesinos y obliga tanto a los jueces

decir, para sanciones graves, el test del paradigma del vivir bien, implicará asegurar que la decisión fue absolutamente necesaria para -en el marco de la inter e intraculturalidad-, resguardar bienes jurídicos superiores amenazados con la conducta sancionada. La ponderación de los cuatro elementos propios del test del paradigma del vivir bien, constituyen un parámetro de ejercicio de control de constitucionalidad en relación a la jurisdicción indígena originario campesina ejercicio que se encuentra circunscrito a la materialización de la constitución axiomática a la luz de valores plurales supremos. En ese orden de ideas, los derechos fundamentales en contextos inter e intraculturales, podrán ser tutelados por el control plural de constitucionalidad; en ese orden, su interpretación deberá ser realizada a la luz de una pauta específica de interpretación inter e intracultural: El paradigma del vivir bien, a cuyo efecto y a través del test precedentemente desarrollado, los derechos fundamentales en el ámbito de la jurisdicción indígena originaria campesina, tendrán plena eficacia, consolidando así una verdadera armonía y paz social”. 
o tribunales de garantías, como al Tribunal Constitucional Plurinacional, a resolver la problemática, de acuerdo a métodos y procedimientos constitucionales interculturales, como ser los peritajes antropológico-culturales o el desarrollo de diálogos en las propias comunidades, para que en caso de verificarse una incompatibilidad de dichos actos o decisiones con los valores antes señalados, se materialice el valor del vivir bien, el cual es el contenido esencial de los derechos individuales o colectivos vigentes en contextos intra e interculturales.

El entendimiento antes descrito, en cada caso concreto debe ser utilizado verificándose la compatibilidad o incompatibilidad de los actos u omisiones denunciados como lesivos con los dos postulados descritos, los cuales componen el paradigma del vivir bien como pauta de interpretación intercultural de derechos fundamentales. Finalmente, debe señalarse que el desarrollo del paradigma del vivir bien en los términos antes señalados, es un razonamiento, conocimiento o saber de carácter esencial para el presente fallo y por tanto genera el precedente jurisprudencial vinculante".

Por otro lado, y respecto al "vivir bien" en el contexto de las naciones y pueblos indígenas, la jurisprudencia constitucional también ha establecido el siguiente entendimiento:

"Dado que según la cosmovisión de los pueblos indigenas, éstos se conducen por la defensa de la vida, la cual está en peligro; para estos pueblos, la tierra no es un espacio sin vida, sino un territorio integral, con su propia estructura, pensamiento, espiritualidad, economía, cultura; ahi se vive y se convive con la naturaleza, se tiene organización con autoridad, idioma, cultura y conocimientos propios. Puesto que la cultura occidental colonizó física y mentalmente a los pueblos indigenas, con una filosofía antropocéntrica, eurocéntrica, individualista, militarista, racista, vertical, acumuladora, depredadora, imponiendo un pensamiento mono cultural, que se refleja en un solo Dios, un solo Estado, un solo simbolo, una sola ley, etc., desconociendo que todos somos parte de la Madre Tierra. Por ello, toda cuestión relativa a los pueblos y naciones indigena originario campesinos, amerita su consideración en aplicación del mandato de la norma suprema del Estado Plurinacional, en cuanto al 'vivir bien' para que ninguno de los miembros asentados en dichos territorios, sufra aislamiento y desatención por parte del Estado.

Asimismo, se debe considerar el 'derecho al desarrollo cosmogónico, natural' como guia de la actuación del Estado enmarcado en el principio del 'vivir bien', donde los indigenas otrora totalmente marginados y excluidos, tengan también el derecho a una vida digna, noble, sin atentar contra su hábitat natural, respetando sus costumbres, lengua y otras formas de expresión cultural de cada pueblo, desterrando la discriminación, el racismo, la marginación, el pensamiento de ser considerado inferior, inculto, incapaz, que no condice con el 'vivir bien', bajo cuyo principio es importante reparar 
la destrucción realizada por invasores criollos y mestizos, quienes desde su visión del mundo, pretenden ahora colaborar con la 'solución de los problemas' creados por ellos mismos. El 'vivir bien' conlleva a una dimensión espiritual, afectiva y social contraria al paradigma occidental que toma en cuenta principalmente la dimensión material y tangible del desarrollo.

En el contexto de las naciones y pueblos indígenas, el 'vivir bien' trata de una forma de vida natural, basada en la convivencialidad, complementariedad y relacionalidad de todo lo que compone la vida, con un enfoque integral y holistico de ésta, donde el 'vivir bien', no es el mundo depredador capitalista que lo destruye todo. Los indígenas no pretenden transformar el mundo, sino amarlo tal como es, con sus loros, tigres, peces y todas las especies existentes. En la cosmovisión de los pueblos indígenas, no se aspira la perfección, sino a la convivencia entre todas las formas de vida natural. Para las naciones y pueblos indigenas todo tiene vida y se desea que todo ser viva, incluso aquellos que se presentan como maleza o plagas, pues todos son seres con vida; es decir, seres con los que se dialoga $y$ conversa y que tienen derecho a vivir. No lleva a violentar el medio natural, no conduce a un trato irrespetuoso de la vida, ni abuso, maltrato o agotamiento de la tierra, ni a la sobreexplotación de su fertilidad y riqueza". (Cfr. Sentencia Constitucional Plurinacional No 2056/2012, de fecha 16 de octubre de 2012).

Asimismo, en cuanto se refiere al "vivir bien" (suma qamaña) como principio ético moral de la sociedad plural, que debe orientar la administración de justicia constitucional, el Tribunal Constitucional Plurinacional ha delineado sus alcances en el siguiente sentido:

“(...) El pueblo boliviano, en la construcción de un nuevo Estado, basado en el respeto e igualdad entre todos, donde predomine la buisqueda del vivir bien, con respeto a la pluralidad jurídica de los habitantes de esta tierra, tiene ese reto histórico de construir colectivamente el Estado Unitario Social de Derecho Plurinacional Comunitario, para avanzar hacia una Bolivia democrática e inspiradora de la paz; este Estado, se funda en la pluralidad jurídica, dentro del proceso integrador del pais; que asume y promueve como principios ético-morales de la sociedad plural: ama qhilla, ama llulla, ama suwa (no seas flojo, no seas mentiroso ni seas ladrón), suma qamaña (vivir bien), ñandereko (vida armoniosa), tekokavi (vida buena), ivimaraei (tierra sin mal) y qhapajñan (camino o vida noble); $y$, se sustenta en los valores de unidad, igualdad, inclusión, dignidad, libertad, solidaridad, reciprocidad, respeto, complementariedad, armonía, transparencia, equilibrio, igualdad de oportunidades, equidad social y de género en la participación, bienestar común, responsabilidad, justicia social, distribución y redistribución de los productos y bienes sociales, para vivir bien; con fines y funciones esenciales del Estado, además de los que establece la Constitución Política del Estado y la ley, constituir una sociedad justa y armoniosa, con plena justicia social, garantizando el cumplimiento de los 
principios, valores, derechos y deberes reconocidos y consagrados en la Norma Suprema. En ese sentido, para el logro del 'vivir bien' (suma qamaña), como objetivo del Estado, en la pluralidad jurídica debe buscar construir una justicia imparcial, transparente, equitativa, pronta, oportuna y sin dilaciones respetando los derechos fundamentales y las normas constitucionales consagradas en la Ley Fundamental, en esa dirección debe estar orientada la justicia constitucional". (Cfr. Sentencia Constitucional Plurinacional No 0076/2013, de fecha 14 de enero de 2013).

\section{La reafirmación del Estado Plurinacional de Bolivia como Estado Constitucional de Derecho ${ }^{11}$}

Con el nacimiento del nuevo Estado Plurinacional, el Tribunal Constitucional, contrastando las características esenciales del modelo de Estado de la Ley Fundamental de 2009, ha reafirmado su carácter de Estado Constitucional de Derecho, según señaló en la Sentencia Constitucional No 0258/2011-R de 16 de marzo, declarando que: "...la Constitución es entendida actualmente no sólo de manera formal, como reguladora de las fuentes del Derecho, de la distribución $y$ del ejercicio del poder entre los órganos estatales, sino como la Ley Suprema que contiene los valores, principios, derechos y garantías que deben ser la base de todos los órganos del poder público, en especial del legislador y del intérprete de la Constitución. Así, en el Estado constitucional de Derecho, las Constituciones tienen un amplio programa normativo, con principios, valores, nutridos catálogos de derechos y garantías, que vinculan a todos los órganos de poder y en general, a toda la sociedad y, en ese sentido, contienen diferentes mecanismos jurisdiccionales y un órgano especializado para velar por el cumplimiento de sus normas, frente a la lesión o incumplimiento, dando vigencia al principio de supremacía constitucional".

Asimismo, la citada Sentencia Constitucional concluyó que: "El modelo de Estado asumido en Bolivia, se constituye en un verdadero Estado constitucional de Derecho, establecido sobre valores universales y el principio fundamental de legalidad, sin desechar los principios generales de soberanía popular en el ejercicio del poder público y reforzando el principio de respeto y vigencia de los Derechos Humanos; pues se establece un amplio catálogo de derechos fun-

11 Tribunal Constitucional Plurinacional, Sentencia Constitucional Plurinacional No 1714/2012, de 1 de octubre de 2012. 
damentales, garantías constitucionales, principios y valores; además, se señalan como fines y funciones del Estado, entre otras, el garantizar el cumplimiento de los principios, valores, derechos y deberes reconocidos y consagrados en la Constitución (art. 9.4 de la CPE), se señalan como deberes de los bolivianos y bolivianas el conocer, cumplir y hacer cumplir la Constitución y las leyes, conocer, respetar y promover los derechos reconocidos en la Constitución, y la práctica de los valores y principios que proclama la Constitución (art. 108 numerales 1, 2 y 3)..." (negrillas añadidas).

Corroborando este razonamiento, el Tribunal Constitucional Plurinacional en la Sentencia Constitucional Plurinacional No 0112/2012 de 27 abril, entendió que: "la supremacía de la Constitución normativa que fundamenta la validez de todo el sistema jurídico plural de normas que la integra (art. 410.11 de la CPE), no es per se (un mero asunto de jerarquias y competencias-pertenencia formal) sino porque está cargada de normas constitucionales-principios que son los valores, principios, derechos y garantías plurales que coexisten, que conviven como expresión de su 'base material pluralista' y se comunican entre sí como expresión de su 'base intercultural' y son los que informan el orden constitucional y legal, sin renunciar a su contenido de unidad (art. 2 de la CPE). De ahi que la Constitución de 2009, si bien es norma jurídica, no puede ser comprendida únicamente sólo de manera formal. Esto significa que no puede ser concebida sólo como un conjunto de normas (modelo descriptivo de Constitución como norma), a partir de un 'concepto de Constitución (como norma) simplemente documental', con las denominaciones de 'constitución formal'o incluso de 'constitución en sentido formal', cuya primacía simplemente se sustente y esté distinguida de las otras leyes por alguna característica formal (por ejemplo, los procedimientos más complicados de producción, revisión y derogación). Por cuanto, lo que esencialmente diferencia a las normas constitucionales de las otras leyes, es que las primeras son prevalentemente normas constitucionales-principios (entiéndase por ello a la pluralidad de valores supremos, principios constitucionales, derechos fundamentales $y$ garantías constitucionales) y supletoriamente normas constitucionales-reglas" (las negrillas son agregadas).

En esta perspectiva, la citada Sentencia Constitucional Plurinacional afirmó que: "Las normas constitucionales-principios, establecidos en la Constitución, son las que influirán en el significado jurídico de las normas constitucionales-reglas y normas legales-reglas (contenidas en las leyes, códigos sustantivos y procesales) y no viceversa, o lo que es lo mismo, las segundas y terceras deben adaptarse a las primeras para que exista coherencia del sistema..." (las negrillas corresponden a la Sentencia). 


\section{La Teoría sobre el Estado Constitucional y su relevancia en Bolivia}

Ahora bien, de acuerdo a los Estudios de Teoría Constitucional de Guastini' ${ }^{12}$, un Estado puede llamarse Constitucional, o provisto de Constitución, sólo si cumple dos condiciones (disyuntivamente necesarias y conjuntivamente suficientes): 1) por un lado, que estén garantizados los derechos de los ciudadanos en sus relaciones con el Estado (lo que se refleja en las Acciones de Defensa que prevé la Constitución boliviana), y 2) por otro lado, que los "poderes" del Estado (en realidad, los órganos de Poder del Estado: Ejecutivo, Legislativo, Judicial y, en nuestro caso, Electoral) estén divididos y separados, es decir, que se ejerzan por órganos diversos (esto en relación al Principio de Separación de Funciones previsto en el artículo 12 constitucional) ${ }^{13}$.

En el caso de Bolivia, la Constitución Política del Estado (2009) se ha ocupado de dar cumplimiento a estas condiciones mínimas para distinguirse como un Estado Constitucional, al declarar expresamente que "Todo ser humano tiene personalidad y capacidad jurídica con arreglo a las leyes y goza de los derechos reco-

12 Guastini (2001), p. 31.

13 En ese entendido, cabe señalar que la Sentencia Constitucional Plurinacional No 0591/2012 de 20 de julio, respecto al principio de separación de poderes, refirió: "El art. 12 de la CPE, consagra el principio de separación de funciones, que ha venido a reemplazar a la clásica teoría de la división de poderes. El principio de división de funciones o división de poderes ha sido establecido como parte de nuestro sistema constitucional desde la primera Constitución Política del Estado, habiendo merecido un detallado estudio por la jurisdicción constitucional; así, sobre la base de lo dispuesto por el art. 2 de la CPE abrg., la SC 0019/2005 de 7 de marzo, ha señalado lo siguiente: '... el principio de la separación de funciones, conocida también en la doctrina clásica del Derecho Constitucional como el principio de la 'división de poderes', implica la distribución de competencias y potestades entre diversos órganos estatales para el ejercicio del poder, de manera que esa distribución se constituya en una limitación para cada órgano de poder, el que sólo podrá ejercer las potestades que forman parte de su competencia. Cabe señalar que, con relación este principio, este Tribunal, mediante su SC 0009/2004 de 28 de enero, ha señalado lo siguiente: 'En el marco del principio fundamental referido, que está consagrado en la norma prevista por el art. 2 de la Constitución, el Constituyente ha efectuado la distribución de funciones y competencias; así la potestad legislativa, de control y fiscalización la tiene el Poder Legislativo; la función ejecutiva, administrativa y reglamentaria la ejerce el Poder Ejecutivo y el ejercicio de la potestad jurisdiccional la tiene el Poder Judicial. (...) Conforme enseña la doctrina del Derecho Constitucional, la concepción dogmática de la 'división de poderes', ha sido superada en el constitucionalismo contemporáneo con la adopción del concepto de la separación de funciones que se sustenta en los siguientes principios: 1) la independencia de los órganos de poder del Estado; 2) la coordinación e interrelación de funciones entre los órganos; y 3) el equilibrio entre los órganos que se establece a partir frenos y contrapesos; ello implica que los diversos órganos de poder del Estado no desarrollan única y exclusivamente su función esencial, también participan en el desempeño de las funciones y labores de los otros órganos, en el marco de las atribuciones y competencias conferidas por el Constituyente, asi el Legislativo participa en las labores del Ejecutivo aprobando el presupuesto general de la nación, o ratificando los tratados internacionales, entre otros; de su parte el Ejecutivo participa en las labores del Legislativo a través de los mecanismos previstos en la Constitución, tales como la iniciativa legislativa, la promulgación de la Ley, entre otras actividades' (...)". 
nocidos por esta Constitución, sin distinción alguna", lo cual implica que el Estado garantiza a todas las personas y colectividades, sin discriminación alguna, el libre y eficaz ejercicio de los derechos establecidos en la Constitución, las leyes y los Tratados Internacionales de Derechos Humanos. De ahí que (según el artículo 13 constitucional), "Los derechos reconocidos por esta Constitución son inviolables, universales, interdependientes, indivisibles y progresivos", por lo que el Estado tiene el deber de promoverlos, protegerlos y respetarlos, considerando que los derechos que proclama la Constitución no serán entendidos como negación de otros derechos no enunciados, a cuyo efecto, los derechos y deberes consagrados en la Constitución se interpretarán de conformidad a lo dispuesto en los tratados internacionales de derechos humanos ratificados por Bolivia.

Asimismo, los rasgos principales de los derechos fundamentales consagrados por la Constitución Política del Estado están contenidos en el artículo 109, que expresa la esencia del reconocimiento de los derechos fundamentales, es decir: 1) Con igualdad jerárquica de todos los derechos constitucionalmente reconocidos; 2) Con directa aplicabilidad de los mismos, es decir, todos, y 3) Con directa justiciabilidad de todos ellos, a través de las acciones y mecanismos de defensa.

Considero que estas características, propias de los derechos fundamentales en el sistema constitucional boliviano, pueden ser entendidas en el siguiente sentido:

$>$ La igualdad jerárquica de los derechos significa básicamente que la clasificación de los derechos establecida en la Constitución no determina jerarquía alguna ni superioridad de unos derechos sobre otros, y ello supone que todos los derechos reconocidos como fundamentales se encuentran situados en un plano de igualdad, por lo que gozan de similares garantías para su optimización y protección integral por parte del Estado, no pudiendo ser perjudicados en su libre ejercicio, salvo por las limitaciones previstas en el ordenamiento jurídico ${ }^{14}$ para el resguardo del bien común.

14 En este sentido, la Declaración Americana de los Derechos y Deberes del Hombre, en su artículo XXVIII, establece: "Los derechos de cada hombre están limitados por los derechos de los demás, por la seguridad de todos y por las justas exigencias del bienestar general y del desenvolvimiento democrático"; asimismo, la Declaración Universal de Derechos Humanos, en su artículo 29.2, indica: "En el ejercicio de sus derechos y en el disfrute de sus libertades, toda persona estará solamente sujeta a las limitaciones establecidas por la ley con el único fin de asegurar el reconocimiento y el respeto de los derechos y libertades de los demás, y de satisfacer las justas exigencias de la moral, del orden público y del bienestar general en una sociedad democrática"; y finalmente, el Pacto Internacional de Derechos Económicos, Sociales y Culturales, en su artículo 4, refiere que: "Los Estados Partes en el presente Pacto reconocen que, en ejercicio de los derechos garantizados conforme al presente Pacto por el Estado, éste podrá someter tales derechos únicamente a limitaciones determinadas por ley, sólo en la medida compatible con la naturaleza de esos derechos y con el exclusivo objeto de promover el bienestar general en una sociedad democrática". Por su parte, la Sentencia Constitucional No 0019/2003, de fecha 28 febrero de 2003, 
Sin embargo, en caso de conflicto, se deberá efectuar una ponderación suficientemente justa y equilibrada, de tal forma que no se llegue a desnaturalizar la esencia de ninguno de ellos; dado que, actuar en sentido contrario, significaría consentir una injusticia y una afrenta inadmisible contra los postulados de la misma Constitución.

La directa aplicación de los derechos significa que ninguno de ellos requiere necesariamente de un desarrollo legislativo para su cumplimiento y concretización, dado que por su reconocimiento constitucional y la fuerza expansiva de las normas de la misma Constitución, éstos se sitúan en un plano preferente de aplicación, considerando que la Constitución es una norma jurídica cualitativamente distinta de las demás y situada por encima de ellas, por lo que la observancia de la carta de derechos es ineludible para todos/as, gobernantes y gobernados, lo que concuerda con el valor del "vivir bien" establecido por la misma Constitución, para lograr el pleno desarrollo de las personas, libres de cualquier arbitrariedad en una sociedad democrática.

$>$ La directa justiciabilidad de los derechos está vinculada a que éstos no son simplemente postulados líricos sin mayor resonancia en el texto constitucional, sino que poseen mecanismos eficaces e idóneos de defensa que la misma Constitución prevé bajo la denominación de "Acciones de Defensa", a fin de asegurar la protección integral e inmediata de los derechos de cualquier persona, en caso de amenaza o vulneración directa e ilegítima por parte de cualquier persona particular y/o autoridad pública o privada, lo que también supone una forma de defensa de la Constitución en su contenido dogmático.

En el caso de Bolivia, el Principio de Aplicación Directa y eficaz de los derechos fundamentales, constituye un postulado que consolida el valor normativo de la Constitución, por el cual los derechos fundamentales tienen una efectividad plena más allá de un reconocimiento legislativo o de formalismos extremos que puedan obstaculizar su plena vigencia, aspecto que caracteriza la "última generación del Constitucionalismo", en el cual el fenómeno de constitucionalización del ordenamiento jurídico ${ }^{15}$ se consagra y alcanza su esplendor a través del principio

señaló: “...que la jurisprudencia constitucional, conforme las normas previstas en la Constitución así como en los tratados, convenciones y convenios internacionales suscritos y ratificados por el Estado boliviano, ha asumido que el ejercicio de los derechos fundamentales tiene limites, en consecuencia las personas no pueden hacer un ejercicio absoluto o arbitrario que lesione los derechos de las otras personas o los intereses generales... ".

15 El Estado Democrático Constitucional de Derecho tiene como característica la generación de un proceso de constitucionalización del ordenamiento jurídico, que consiste principalmente en la transformación de un ordenamiento jurídico, al término del cual el mismo resulta totalmente impregnado por las normas constitucionales, de manera que la finalidad de ese proceso es que el Estado Constitucional cuente con un ordenamiento jurídico constitucionalizado, que se caracterice por tener una Constitución totalmente invasora, 
de aplicación directa de los derechos fundamentales, el cual se materializa a través del nuevo rol de las autoridades jurisdiccionales en su labor de interpretación constitucional acompañada de una coherente teoría de argumentación jurídica. En este sentido, el TCP ha explicado los alcances del Principio de Aplicación Directa y eficaz de derechos fundamentales en el orden constitucional vigente, en los siguientes términos:

"El régimen constitucional vigente a partir del referendo constitucional de 2009, diseña un nuevo modelo de Estado, cuyo sustento estructural, encuentra razón de ser en el respeto a los derechos fundamentales insertos en el bloque de constitucionalidad, reconocido por el art. 410 de la CPE, en ese contexto, este pilar esencial del Estado Plurinacional de Bolivia encuentra validez material en el reconocimiento expreso del principio de aplicación directa de derechos fundamentales el cual se encuentra taxativamente reconocido por el art. 109. I de la CPE, cuyo tenor señala: 'Todos los derechos reconocidos en la Constitución

cuya fuerza expansiva sea capaz de condicionar tanto la legislación como la jurisprudencia y la doctrina, la acción de los actores políticos, así como las relaciones sociales. En este sentido, y de acuerdo a la doctrina contemporánea del Derecho Constitucional, para que el ordenamiento jurídico del Estado se considere constitucionalizado, es necesario que se cumpla básicamente con las siguientes condiciones: a) Una Constitución rígida, esto es, que la Ley Fundamental no pueda ser modificada en cualquier momento por los órganos del poder constituido y mediante los mecanismos previstos para la modificación de las leyes ordinarias, sino únicamente mediante la instalación de un Poder Constituyente derivado y siempre a través de la utilización de procedimientos especiales para su reforma; b) La garantía jurisdiccional de la Constitución, lo que significa que necesariamente deberá crearse un órgano estatal independiente, autónomo y especializado que desarrolle el control de constitucionalidad con facultades decisorias, cuyas resoluciones tengan carácter obligatorio y la doctrina creada por el mismo tenga efecto vinculante; c) La "sobreinterpretación" de la Constitución, es decir, que la Ley Fundamental que consagra los valores supremos, los principios fundamentales, además de los derechos y garantías constitucionales de la persona, debe merecer una constante interpretación -por parte del órgano contralor de constitucionalidad creado al efecto-para lograr que la Constitución formal responda y concuerde con la Constitución material, de manera tal que aquella sea una norma viva (y permanezca vigente en el tiempo sin caer en desuso); ello obligará al intérprete máximo a extraer las normas implícitas consignadas por el constituyente en el texto de la Constitución; d) La aplicación directa de las normas constitucionales, lo que supone un cambio radical de concepción sobre los alcances de la Ley Fundamental del Estado, pues a diferencia de la concepción clásica, en que la Constitución era considerada una mera carta política que definía la organización y funcionamiento de los órganos del poder público, en el constitucionalismo contemporáneo se considera que la Constitución es la norma fundamental que consigna los valores supremos, principios fundamentales y asimismo consagra derechos fundamentales de la persona, por lo que se hace aplicable a las relaciones de los ciudadanos con el Estado, constituyéndose en un instrumento útil para la solución de conflictos especificos de relevancia constitucional; e) La interpretación de las leyes conforme a la Constitución, ello significa que, en aplicación de los principios fundamentales de la supremacía constitucional y jerarquía normativa, la legislación ordinaria siempre debe ser interpretada desde y conforme a la Constitución para su aplicación en la solución de un caso concreto, de manera que sólo será aplicable aquella interpretación que sea compatible con la Constitución, descartando aquella interpretación que sea contraria o contradictoria con los preceptos contenidos en la Ley Fundamental del Estado. Rivera (2006b), p. 129. 
son directamente aplicables y gozan de iguales garantias para su protección'. El principio de aplicación directa de la Ley Fundamental, que además por antonomasia comprende a la aplicación eficaz de derechos, está intimamente ligado con el valor axiomático de la Constitución, postulado a partir del cual, el fenómeno de constitucionalización o de irradiación del contenido de la Constitución en el orden jurídico y social, no se realizará solamente en cuanto a las normas positivas de rango constitucional, sino también en relación a las directrices axiomáticas rectoras del orden jurídico e institucional del Estado Plurinacional de Bolivia, como ser los valores justicia e igualdad, razón por la cual, solamente a partir de esta concepción puede sustentarse la eficacia del valor normativo de la Constitución.

En el marco de lo señalado, el valor normativo de la Constitución axiomática, como es el caso del texto aprobado en 2009, asegura la aplicación directa y eficaz de los derechos fundamentales a través de la labor interpretativa o hermenéutica de las autoridades jurisdiccionales, cuyas decisiones deben enmarcarse en los valores justicia e igualdad, como postulados esenciales del principio de razonabilidad de las decisiones, el que a su vez, irradiará el contenido esencial de los derechos fundamentales y consolidará la vigencia plena del Estado Constitucional de Derecho". (Cfr. Sentencia Constitucional Plurinacional No 0121/2012, de fecha 2 de mayo de 2012).

Por otro lado, el rango constitucional de los derechos humanos reconocidos en los Tratados Internacionales también ha sido incorporado a la Constitución boliviana, por efecto de la Asamblea Constituyente instalada el año 2007 (lo que inscribe a nuestro país dentro de la corriente del nuevo constitucionalismo latinoamericano), cuyo texto definitivo fue aprobado por referendo popular el año 2009.

En el caso de Bolivia, la misma Constitución (en su artículo 410, parágrafo II), además de declarar que es la norma suprema del ordenamiento jurídico boliviano -gozando de primacía frente a cualquier otra disposición normativa-, establece el Principio de Jerarquía Normativa, por el cual la Constitución ocupa el primer lugar dentro de la estructura jurídica del Estado Plurinacional de Bolivia; es decir, se sitúa en la cúspide de nuestra pirámide jurídica, como principio y fundamento de todas las demás normas; y en segundo lugar, se encuentran los Tratados Internacionales, que pueden ser suscritos en cualquier materia por las autoridades legitimadas al efecto, respondiendo a los fines del Estado "en función de la soberanía y de los intereses del pueblo" (artículo 255, parágrafo I constitucional), dado que una vez ratificados, también llegan a formar parte del ordenamiento jurídico con rango de leyes (artículo 257, parágrafo I constitucional).

Es diferente la situación de los Tratados Internacionales sobre Derechos $\mathrm{Hu}$ manos, porque una vez ratificados, éstos prevalecen en el orden interno, dado que los derechos y deberes constitucionales deben interpretarse conforme a ellos 
(artículo 13, parágrafo IV constitucional), y cuando dichos tratados "declaren derechos más favorables a los contenidos en la Constitución, se aplicarán de manera preferente sobre ésta", vale decir, que los derechos reconocidos en la Constitución "serán interpretados de acuerdo a los tratados internacionales de derechos humanos cuando éstos prevean normas más favorables" (artículo 256 constitucional, que consagra el Principio pro homine).

Entonces, es por demás evidente el tratamiento diferenciado que se otorga a los Tratados Internacionales, de acuerdo a la materia que pretenden regular, más aún si se considera que el Estado Plurinacional de Bolivia, a través de la Constitución, ha decidido seguir la tendencia de otorgar una jerarquía constitucional con aplicación preferencial a los tratados y/o convenciones internacionales que consagran derechos humanos a favor de los(as) ciudadanos(as).

\section{Desarrollo Jurisprudencial del Bloque de Constitucionalidad}

Debemos comenzar citando a Francisco Rubio Llorente, quien nos ofrece un concepto introductorio del Bloque de Constitucionalidad, anotando que en la doctrina de Francia -país en donde se originó el Bloc de Constitutionalité, por una resolución del Consejo Constitucional francés, el 8 de julio de 1966- se utiliza este término para designar al conjunto de normas que el Consejo Constitucional aplica en el control previo de constitucionalidad de las normas ${ }^{16}$. Por su parte, Bidart Campos sostiene que "el Bloque de constitucionalidad es el conjunto normativo que contiene disposiciones, principios o valores materialmente constitucionales, fuera de la Constitución documental'17. Para Mónica Arango el Bloque de Constitucionalidad son "aquellas normas y principios que, sin aparecer formalmente en el articulado del texto constitucional, son utilizados como parámetros de control de constitucionalidad de las leyes, por cuanto han sido normativamente integrados a la Constitución, por diversas vías y por mandato de la propia Constitución". ${ }^{18}$

Entonces, se puede concluir señalando que son parte del Bloque de Constitucionalidad aquellas normas, principios y valores que, sin ser parte del texto constitucional, por disposición o mandato de la propia Constitución, se integran

\footnotetext{
16 Rubio (1991), p. 105.

17 BIDART (1995), p. 264.

18 Arango (2004), p. 1. La autora fundamenta su concepto de bloque de constitucionalidad en: Corte Constitucional de Colombia, Sentencia C-225-95, MP Alejandro Martínez Caballero; posición reiterada en la Sentencia C-578-95, MP Eduardo Cifuentes Muñoz; Sentencia C-358-97, MP Eduardo Cifuentes Muñoz, y en Sentencia C-191-98, MP Eduardo Cifuentes Muñoz.
} 
a ella con la finalidad de llevar a cabo el control de constitucionalidad. Una síntesis de estos criterios ahora se encuentra plasmada en el texto de la Constitución Política del Estado Plurinacional de Bolivia, cuando dispone que "el bloque de constitucionalidad está integrado por los Tratados y Convenios internacionales en materia de Derechos Humanos y las normas de Derecho Comunitario, ratificados por el país. (...)" (artículo 410, parágrafo II constitucional).

Este precepto referido al Bloque de Constitucionalidad, constituye una reivindicación de las líneas jurisprudenciales establecidas con anterioridad por la jurisprudencia constitucional ${ }^{19}$, dado que el extinto Tribunal Constitucional, en los Fundamentos Jurídicos contenidos en la Sentencia Constitucional No 0045/2006 de 2 de junio, había precisado que la teoría del bloque de constitucionalidad surgió en Francia, extendiéndose luego a los países europeos, siendo asimilada en Latinoamérica; entendiendo que dicha teoría expone que aquellas normas que no forman parte del texto de la Constitución, pueden formar parte de un conjunto de preceptos que por sus cualidades intrinsecas se deben utilizar para develar la constitucionalidad de una norma legal; así, las jurisdicciones constitucionales agregan, para efectuar el análisis valorativo o comparativo a su Constitución, normas a las que concede ese valor supralegal que las convierte en parámetro de constitucionalidad.

De ahí que la jurisdicción constitucional boliviana ha concedido al bloque de constitucionalidad un alcance perceptible en la Sentencia Constitucional No 1420/2004-R, de 6 de septiembre, estableciendo lo siguiente: “(...) conforme ha establecido este Tribunal Constitucional, a través de su jurisprudencia, los tratados, convenciones o declaraciones internacionales sobre derechos humanos a los que se hubiese adherido o suscrito y ratificado el Estado boliviano forman parte del bloque de constitucionalidad y los derechos consagrados forman parte del catálogo de los derechos fundamentales previstos por la Constitución."; entendimiento ratificado en la Sentencia Constitucional No 1662/2003-R, de 17 de noviembre, en la que expresó: “(...) este Tribunal Constitucional, realizando la interpretación constitucional integradora, en el marco de la cláusula abierta prevista por el art. 35 de la Consti-

19 Desde el año 2001, el Tribunal Constitucional de Bolivia, asumiendo una posición de activismo judicial respecto a la protección de los derechos humanos, ha definido que los tratados, convenciones o pactos internacionales sobre derechos humanos forman parte del bloque de constitucionalidad, por lo que los derechos humanos consagrados en dichos instrumentos forman parte del catálogo de derechos fundamentales previsto por la Constitución; de manera que en ese contexto pueden ser invocados por las personas y tutelados por las autoridades. Tribunal Constitucional de Bolivia, Sentencias Constitucionales: SC 95/01, SC 1662/2003-R y SC 0102/2003. 
tución (de 1994), ha establecido que los tratados, las declaraciones y convenciones internacionales en materia de derechos humanos, forman parte del orden jurídico del sistema constitucional boliviano como parte del bloque de constitucionalidad, de manera que dichos instrumentos internacionales tienen carácter normativo y son de aplicación directa, por lo mismo los derechos en ellos consagrados son invocables por las personas y tutelables a través de los recursos de hábeas corpus y amparo constitucional conforme corresponda".

De la jurisprudencia glosada se deduce que el bloque de constitucionalidad en Bolivia lo conforman, además del texto de la Constitución, los tratados, las declaraciones y convenciones internacionales en materia de derechos humanos ratificados; entonces, queda claro que no todo tratado, declaración, convención o instrumento internacional es parte del bloque de constitucionalidad, sino sólo aquellos que habiendo sido previamente ratificados por el Estado boliviano, estén destinados a la promoción, protección y vigencia efectiva de los derechos humanos, constituyéndose en un parámetro efectivo de constitucionalidad.

Ampliando estos criterios jurisprudenciales, respecto a los elementos del Sistema Interamericano de Derechos Humanos que también conforman el Bloque de Constitucionalidad en Bolivia, el Tribunal Constitucional recientemente sostuvo que:

"los elementos normativos y las decisiones jurisdiccionales que emanen de este sistema no son aislados e independientes del sistema legal interno, de hecho, la efectividad en cuanto a la protección de los derechos fundamentales, solamente está garantizada en tanto y cuanto el orden interno asuma en lo referente a su contenido los alcances y efectos de estas normas $y$ decisiones emergentes del Sistema Interamericano de Protección de Derechos Humanos. En efecto, la doctrina del bloque de constitucionalidad reconocida por el art. 410 de la CPE, contempla como parte del mismo a los Tratados Internacionales referentes a Derechos Humanos, entre los cuales inequivocamente se encuentra el Pacto de San José de Costa Rica, denominado también Convención Interamericana de Derechos Humanos, ratificado por Bolivia mediante Ley No 1599 de 18 de octubre de 1994, norma que por su esencia y temática se encuentra amparada por el principio de supremacía constitucional, postulado a partir del cual, se sustenta el eje estructural de la jerarquía normativa imperante en el Estado Plurinacional de Bolivia.

En efecto, el Pacto de San José de Costa Rica, como norma componente del bloque de constitucionalidad, está constituido por tres partes esenciales, estrictamente vinculadas entre si: la primera, conformada por el preámbulo, la segunda denominada dogmática $y$ la tercera referente a la parte orgánica. Precisamente, el Capitulo VIII de este instrumento regula a la Corte Interamericana de Derechos Humanos, en consecuencia, siguiendo un 
criterio de interpretación constitucional 'sistémico', debe establecerse que este órgano y por ende las decisiones que de él emanan, forman parte también de este bloque de constitucionalidad (...)".

Finalmente concluyó estableciendo que al ser la Corte Interamericana de Derechos Humanos el último y máximo garante en el plano supranacional del respeto a los Derechos Humanos, "el objeto de su competencia y las decisiones que en ejercicio de ella emanan, constituyen piedras angulares para garantizar efectivamente la vigencia del 'Estado Constitucional', que contemporáneamente se traduce en el Estado Social y Democrático de Derecho, cuyos ejes principales entre otros, son precisamente la vigencia de los Derechos Humanos y la existencia de mecanismos eficaces que los hagan valer, por eso es que las Sentencias emanadas de este órgano forman parte del bloque de constitucionalidad y fundamentan no solamente la actuación de los agentes públicos, sino también subordinan en cuanto a su contenido a toda la normativa infraconstitucional vigente. (...) En el marco del panorama descrito, se colige que inequivocamente las Sentencias emanadas de la CIDH, por su naturaleza y efectos, no se encuentran por debajo ni de la Constitución Política del Estado tampoco de las normas jurídicas infraconstitucionales, sino por el contrario, forman parte del bloque de constitucionalidad y a partir del alcance del principio de supremacía constitucional que alcanza a las normas que integran este bloque, son fundamentadoras e informadoras de todo el orden jurídico interno, debiendo el mismo adecuarse plenamente a su contenido para consagrar asi la vigencia plena del 'Estado Constitucional' enmarcado en la operatividad del Sistema Interamericano de Protección a Derechos Humanos". (Cfr. Sentencia Constitucional No 110/2010-R, de fecha 10 de mayo de 2010) ${ }^{20}$.

20 Con bastante anticipación a este entendimiento, el anterior Tribunal Constitucional ya había dejado establecido que la jurisprudencia emanada de la Corte Interamericana de Derechos Humanos tiene fuerza vinculante para el Estado boliviano y sus autoridades; así, en la Sentencia Constitucional No 0491/2003-R, de 15 de abril, a tiempo de resolver una problemática referida a la vulneración del derecho al juez natural, señaló lo siguiente: "uno de los elementos esenciales de la garantía del debido proceso es el derecho al juez natural competente, independiente e imparcial; debiendo entenderse por Juez competente aquel que de acuerdo a las normas jurídicas previamente establecidas, conforme criterios de territorio, materia y cuantía, es el llamado para conocer y resolver una controversia judicial; Juez independiente aquel que, como se tiene referido, resuelve la controversia exenta de toda injerencia o intromisión de otras autoridades o poderes del Estado; y Juez imparcial aquel que decida la controversia judicial sometida a su conocimiento exento de todo interés o relación personal con el problema, manteniendo una posición objetiva al momento de adoptar su decisión y emitir la resolución. El cumplimiento de estos requisitos que hacen al juez natural permite garantizar la correcta determinación de los derechos y obligaciones de las personas; de ahi que la Corte Interamericana de Derechos Humanos, cuya jurisprudencia es vinculante para la jurisdicción interna, en su Sentencia de 31 de enero de 2001 (Caso 
En resumen, y conforme se ha detallado en la Declaración Constitucional Plurinacional No 0003/2013, de fecha 25 de abril de 2013, el bloque de constitucionalidad imperante en el Estado Plurinacional de Bolivia está compuesto por los siguientes compartimentos: 1) La Constitución como norma positiva; 2) Los tratados internacionales referentes a Derechos Humanos, y 3) Las Normas Comunitarias; sin embargo, en el marco de una interpretación progresiva, acorde al principio de unidad constitucional y enmarcada en las directrices principistas del Estado Plurinacional de Bolivia, debe establecerse además que los valores plurales supremos del Estado Plurinacional de Bolivia, como ser el vivir bien, la solidaridad, la justicia, la igualdad material, entre otros, forman parte del bloque de constitucionalidad en un componente adicional, el cual se encuentra amparado también por el Principio de Supremacía Constitucional21.

Tribunal Constitucional del Perú, párrafo 77), ha establecido que 'toda persona sujeta a juicio de cualquier naturaleza ante un órgano del Estado deberá contar con la garantía de que dicho órgano sea competente, independiente e imparcial' (...)" (el resaltado me corresponde). De la misma forma se procedió, al momento de evaluar la constitucionalidad de una disposición legal, cuando a tiempo de analizar el principio de igualdad jurídica, la Sentencia Constitucional No 0058/2003, de 25 de junio, estableció entre sus fundamentos jurídicos lo siguiente: "La noción de igualdad se desprende directamente de la unidad de naturaleza del género humano y es inseparable de la dignidad esencial de la persona, como reconoce la Opinión Consultiva $4 / 84$ de 19 de enero de 1984 de la Corte Interamericana de Justicia. (...)” (el resaltado me corresponde). Respecto al Bloque de Constitucionalidad y su incidencia en los Procesos de Inconstitucionalidad, resulta de enorme utilidad consultar el trabajo de CARPIO (2005), pp. 79-114. Asimismo, sobre la importancia de la jurisprudencia internacional en materia de Derechos Humanos, es de utilidad consultar a AYALA (2003). Finalmente, se debe anotar que, respecto al efecto útil y vinculante de los fallos de la Corte Interamericana de Derechos Humanos, así como el fundamento de dicha obligatoriedad deducida de la normativa y la jurisprudencia internacional, resulta de enorme utilidad el interesante trabajo de ARIAS (2012), pp. 74-94.

21 En este sentido se pronunció la Sentencia Constitucional Plurinacional No 1227/2012, de fecha 7 de septiembre de 2012, en la cual se precisó lo siguiente: “(...) En el orden de ideas expresado, es menester resaltar que a la luz de la Constitución Axiomática y en el marco de los principios de pluralismo e interculturalidad, como elementos de construcción estructural del Estado, es imperante realizar un redimensionamiento y una interpretación extensiva del bloque de constitucionalidad disciplinado por el art. 410.11 de la Constitución; por tanto, para una real materialización de la Constitución Axiomática, se tiene que este bloque, amparado por el principio de supremacia constitucional, estará conformado por los siguientes compartimentos: i) Por la Constitución como texto escrito; ii) Los tratados internacionales vinculados a Derechos Humanos; iii) las normas de derecho comunitario ratificadas por el país, y iv) En una interpretación sistémica, extensiva y acorde con el valor axiomático de la Constitución, se establece además que el Bloque de Constitucionalidad debe estar conformado por un compartimento adicional: los principios y valores plurales supremos inferidos del carácter intercultural y del pluralismo axiomático contemplado en el orden constitucional imperante. Ahora bien, en este estado de cosas, de acuerdo a los compartimentos antes referidos, corresponde precisar que este bloque de constitucionalidad es directamente aplicable en cuanto a la parte dogmática de la Constitución, los derechos humanos insertos en Tratados Internacionales y los principios plurales supremos; empero, la parte orgánica de la Constitución, comprendida como elemento del bloque de constitucionalidad, no es directamente aplicable, sino que para su materialización, se necesitan leyes orgánicas de desarrollo". 
Así, también, en el marco de la nueva visión del constitucionalismo del Estado Plurinacional de Bolivia, formarán parte de este compartimento del bloque de constitucionalidad todos los principios generales del derecho; entonces, según el TCP:

"se colige que la interpretación del bloque de constitucionalidad, en una concepción extensiva y en armonía con los mandatos constitucionales establecidos en el art. 13.IV y 256 de la CPE, en tópicos vinculados a Derechos Humanos, comprende además la pauta de interpretación 'desde y conforme al bloque de convencionalidad', razón por la cual, en mérito a una interpretación progresiva, los derechos amparados por el principio de supremacía constitucional, están integrados por los expresamente disciplinados en el texto constitucional y todos aquellos reconocidos por el bloque de convencionalidad, en el ámbito de una aplicación siempre guiada a la luz del principio de favorabilidad".

Conforme a lo expuesto, se puede inferir que la jurisprudencia constitucional ha realizado un redimensionamiento del bloque de constitucionalidad y del Estado Constitucional de Derecho a la luz del pluralismo y la interculturalidad, dado que la inserción en el Bloque de Constitucionalidad de valores plurales y principios supremos rectores del orden constitucional tiene una relevancia esencial, ya que merced al principio de supremacía constitucional aplicable al bloque de constitucionalidad boliviano, operará el fenómeno de constitucionalización, no solamente en relación a normas supremas de carácter positivo, sino también en relación a valores y principios supremos rectores del orden constitucional, aspecto que, en definitiva, consolidará el carácter axiomático de la Constitución Política del Estado aprobada en 2009.

En este redimensionamiento del bloque de constitucionalidad y del Estado Constitucional de Derecho, se colige que a la luz del vivir bien, la justicia y la igualdad como principios y valores plurales supremos que forman parte del bloque de constitucionalidad imperante, irradiarán de contenido todos los actos de la vida social, consagrando así los postulados propios del Estado Constitucional de Derecho. (Cfr. Sentencia Constitucional Plurinacional No 0683/2013, de fecha 3 de junio de 2013).

\section{Conclusión}

En definitiva, el desarrollo jurisprudencial de los principios ético-morales de nuestra sociedad plural, consagrados por la Constitución, así como el bloque de constitucionalidad que, por mandato constitucional, está integrado por todos aquellos instrumentos internacionales de protección de derechos humanos, rati- 
ficados en legal forma por el Estado Plurinacional de Bolivia, es una importante señal de desarrollo intenso que está teniendo la propia Constitución, y la disciplina encargada de poner en movimiento sus postulados esenciales, cual es el Derecho Procesal Constitucional.

Hasta aquí, he intentado rescatar lo más importante de la jurisprudencia constitucional plurinacional, respecto al entendimiento que debe asumirse en cuanto a la naturaleza y alcance de los principios ético-morales establecidos por la Constitución Política del Estado aprobada el año 2009, la reafirmación del Estado Unitario Social de Derecho Plurinacional Comunitario como Estado Constitucional de Derecho, y el redimensionamiento del Bloque de Constitucionalidad en Bolivia, esperando sea de utilidad para los lectores, con el compromiso de volver sobre estos y otros temas de análisis jurisprudencial derivados de la Constitución.

\section{BibLIOGRAFÍA CITADA}

Arango Olaya, Mónica (2004). El bloque de constitucionalidad en la jurisprudencia de la Corte Constitucional colombiana, p. 1. (Consultado en agosto de 2015). Disponible en: http://www.icesi.edu.co/contenido/pdfs/C1C-marangobloque.pdf.

Arias López, Boris (2012). "Fundamentos de la obligatoriedad de las Sentencias de la Corte Interamericana de Derechos Humanos". En: Lex Social: Revista de los Derechos Sociales, ISSN-e 2174-6419, No 1, 2012. pp. 74-94. (Consultado en agosto de 2015). Disponible en: http://dialnet.unirioja.es/servlet/ articulo? codigo $=3890744)$.

Ayala Corao, Carlos (2003). "Recepción de la Jurisprudencia Internacional sobre Derechos Humanos por la Jurisprudencia Constitucional”. En: TRIBUnal Constitucional de Bolivia (editor): La Justicia Constitucional en Bolivia 1998-2003. (Cochabamba, Bolivia. Grupo Editorial Kipus).

Bidart Campos, Germán (1995). El Derecho de la Constitución y su fuerza normativa (Buenos Aires, Ediar).

Carpio Marcos, Edgar (2005). "Bloque de Constitucionalidad y proceso de inconstitucionalidad de las leyes". En: Revista Iberoamericana de Derecho Procesal Constitucional. Proceso y Constitución. No 4. (México: Editorial Porrúa).

Durán Ribera, Willman (2005). Principios, Derechos y Garantías Constitucionales. (Santa Cruz-Bolivia: Comunicaciones El País).

Guastini, Riccardo (2001). Estudios de Teoría Constitucional. (México D.F.: Instituto de Investigaciones Jurídicas-UNAM). 
Rivera SantiváŃEZ, José Antonio (2006a). “Hasta dónde reformar la Constitución?” Revista Opiniones y Análisis. No 78. Temas para la Asamblea Constituyente. Tomo I. (La Paz-Bolivia: Fundemos y Fundación Hanns Seidel Stiftung).

Rivera Santivánez, José Antonio (2006b). "El Tribunal Constitucional en el Nuevo Modelo de Estado". En: IX Seminario Internacional: "Justicia Constitucional y Estado de Derecho" (La Paz, 7 al 9 de junio de 2006). Memoria No 10. (Sucre, Bolivia: Imprenta "Imag").

Rivera Santiváñez, José Antonio (2008). Hacia una Nueva Constitución. Luces y Sombras del Proyecto modificado por el Parlamento. (Cochabamba, Bolivia: Fundación Konrad Adenauer, Fundappac y Oficina Jurídica para la Mujer). Rubio Llorente, Francisco (1991). El Bloque de la constitucionalidad. Simposium franco-español de Derecho Constitucional. (Madrid: Universidad de Sevilla, Civitas).

\section{JURISPRUDENCIA CITADA}

Sentencia Constitucional No 0019/2003, de fecha 28 febrero de 2003.

Sentencia Constitucional No 0491/2003-R, de fecha 15 de abril de 2003.

Sentencia Constitucional No 0058/2003, de fecha 25 de junio de 2003.

Sentencia Constitucional No 0019/2010-R, de fecha 13 de abril de 2010.

Sentencia Constitucional Plurinacional No 0110/2012, de fecha 27 de abril de 2012.

Sentencia Constitucional Plurinacional No 0112/2012, de fecha 27 de abril de 2012.

Sentencia Constitucional Plurinacional No 0591/2012, de fecha 20 de julio de 2012.

Sentencia Constitucional Plurinacional No 1227/2012, de fecha 7 de septiembre de 2012.

Sentencia Constitucional Plurinacional No 1714/2012, de fecha 1 de octubre de 2012.

Sentencia Constitucional Plurinacional No 1240/2013, de fecha 1 de agosto de 2013.

Sentencias del Tribunal Constitucional de España, de 31 de marzo de 1981 y de 28 de abril de 1982 . 